
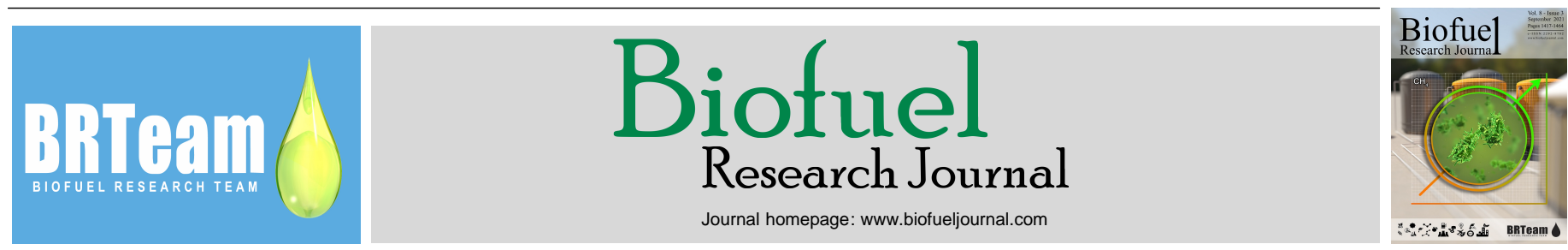

Original Research Paper

\title{
Distillery decarbonisation and anaerobic digestion: balancing benefits and drawbacks using a compromise programming approach
}

\author{
Richard O'Shea ${ }^{1,2, *}$, Richen Lin ${ }^{1,2}$, David M. Wall ${ }^{1,2}$, James D. Browne ${ }^{3}$, Jerry D. Murphy ${ }^{1,2}$ \\ ${ }^{1}$ MaREI Centre, Environmental Research Institute, University College Cork, Cork, Ireland. \\ ${ }^{2}$ Civil, Structural and Environmental Engineering, School of Engineering and Architecture, University College Cork, Cork, Ireland. \\ ${ }^{3}$ Irish Distillers Limited, Midleton Distillery, Midleton, Co. Cork, Ireland.
}

\section{HIGHLIGHTS}

$>$ Maximising the benefits of biogas also maximises the potential drawbacks.

$>$ Compromise programming $(\mathrm{CP})$ assessed 9,621 scenarios of biogas production.

$>$ Preferences of distillery management were accounted for in the $\mathrm{CP}$ analysis.

$>$ CP suggests an optimal biogas system uses $100 \%$ of thick stillage and $100 \%$ of draff. $>$ Scope 1 emissions are reduced by $45 \%$ when using the optimal biogas system.

\section{GRAPHICAL ABSTRACT}

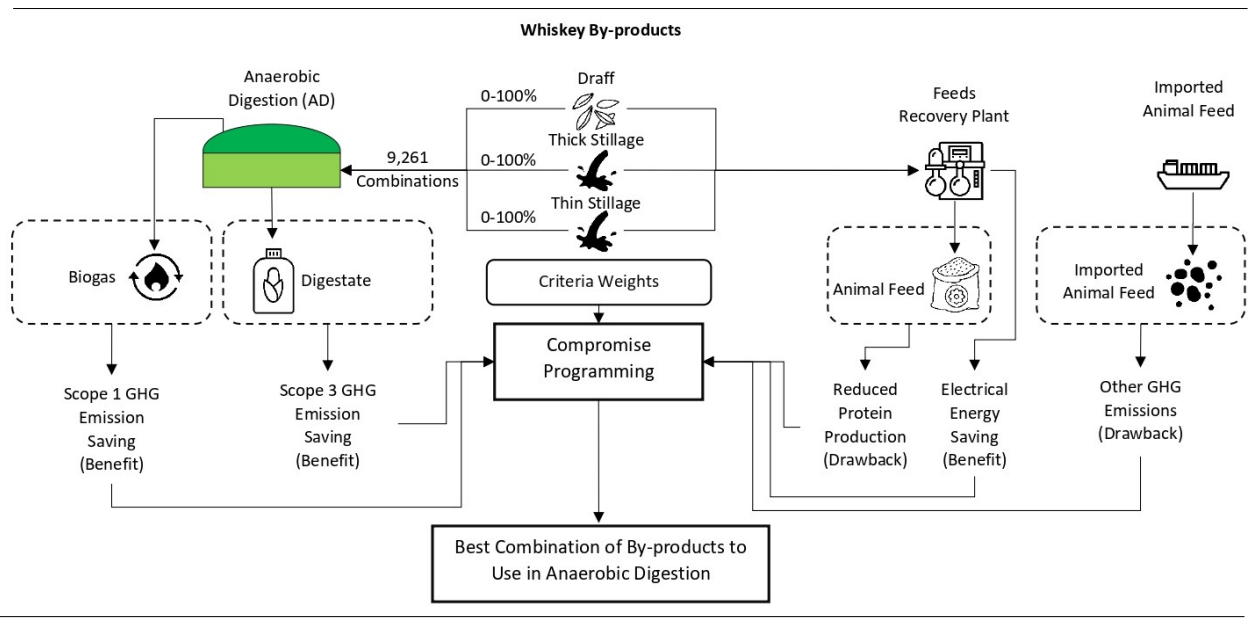

\section{ARTICLE INFO}

\begin{abstract}
The anaerobic digestion (AD) of distillery by-products presents benefits such as greenhouse gas (GHG) emission savings and electricity savings, as well as drawbacks such as reduced animal feed and protein production and the potential import of animal feeds. This work balances these benefits and drawbacks using compromise programming (CP). The best combination of byproducts (from 9,261 scenarios) to use in $\mathrm{AD}$ was selected based on criteria chosen by management of a large distillery. The use of all by-products maximises benefits and drawbacks; the contrary also applies. When benefits and drawbacks are equally important, $\mathrm{CP}$ recommends using $50 \%$ of available draff, $50 \%$ of available thick stillage, and $55 \%$ of available thin stillage. The best combination when accounting for criteria weights chosen by distillery management is the use of $100 \%$ of available draff and $100 \%$ of available thick stillage. This could replace $48 \%$ of natural gas consumption at the distillery, reduce Scope 1 emissions by $45 \%$, achieve a Scope 3 emissions savings of $22 \%$ of current Scope 1 emissions, and reduce electricity consumption in the feeds recovery plant of the distillery by $63 \%$. Protein loss of $9,618 \mathrm{t}$ could require the import of 19.59 kilo-tonne wet weight of material (ktwwt) of distillers grains and $9.15 \mathrm{ktwwt}$ of soybean meal. If different criteria or criteria weights were used, a different result would be recommended. The methodology developed herein can aid in decarbonising the food and beverage industry by allowing decision-makers to balance the benefits and drawbacks of $\mathrm{AD}$ while accounting for subjective preferences.
\end{abstract}

(C) 2021 BRTeam. All rights reserved.

* Corresponding author at: Tel.: +353 (0)21 4901971

E-mail address: richard.oshea@ucc.ie

Please cite this article as: O'Shea R., Lin R., Wall D.M., Browne J.M., Murphy J.D. Distillery decarbonisation and anaerobic digestion: balancing benefits and drawbacks using a compromise programming approach. Biofuel Research Journal 31 (2021) 1417-1432. DOI: 10.18331/BRJ2021.8.3.2 


\section{Contents}

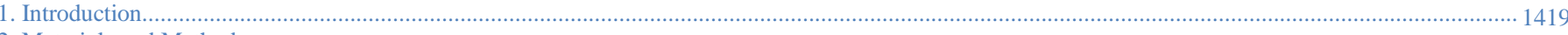

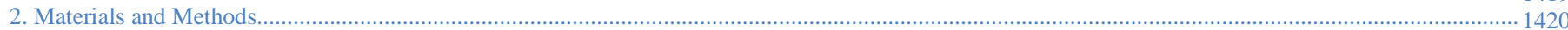

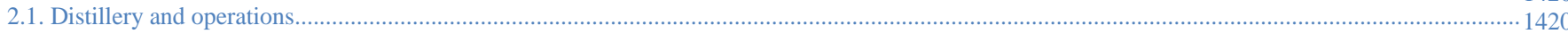

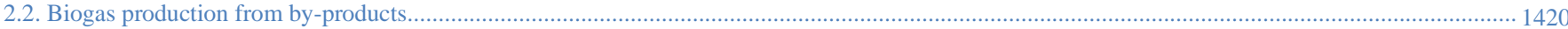

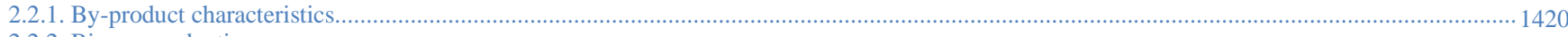

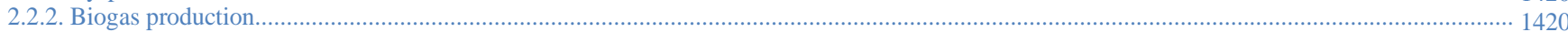

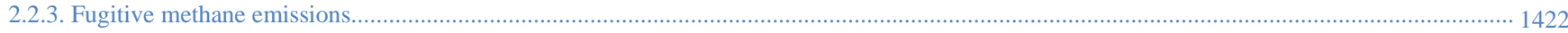

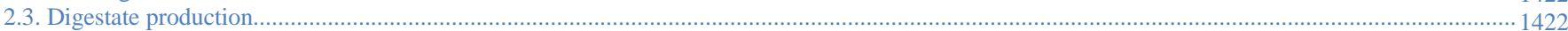

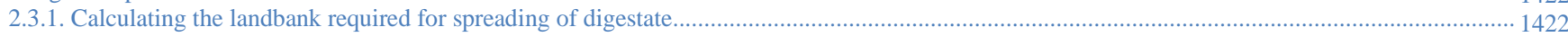

2.3.2. Calculating the impact of digestate use on GHG emissions associated with barley cultivation...................................................................... 1423

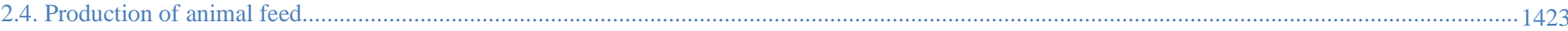

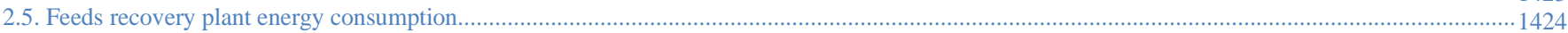

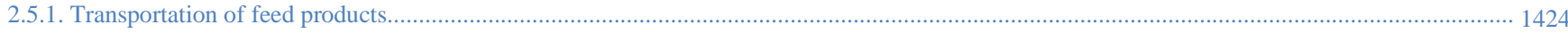

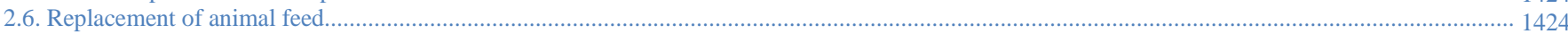

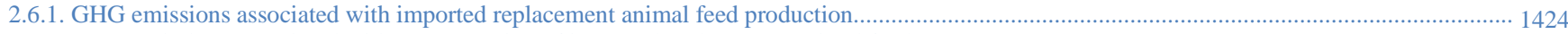

2.6.2. GHG emissions associated with transportation of imported replacement animal feed......................................................................................... 1424

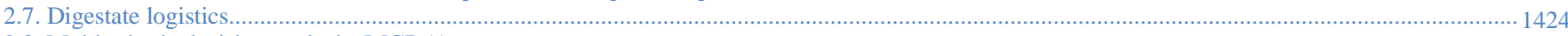

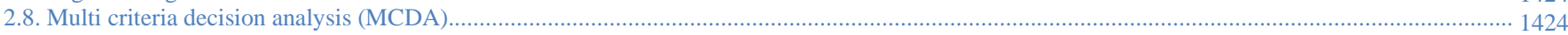

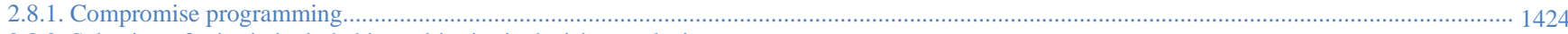

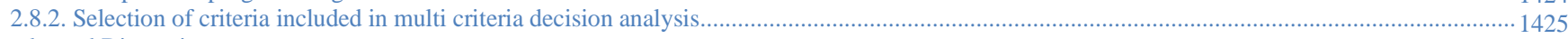

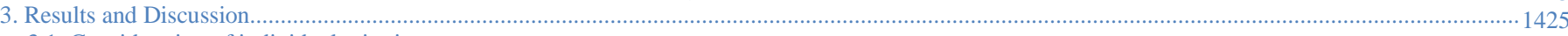

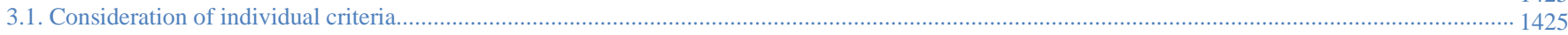

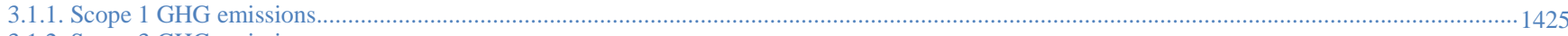

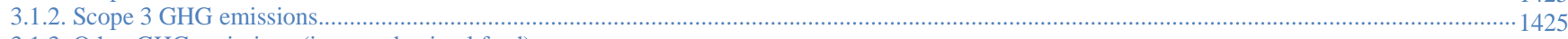

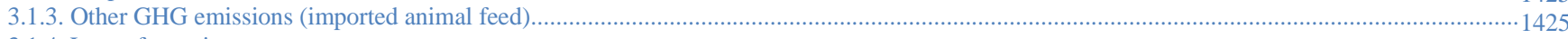

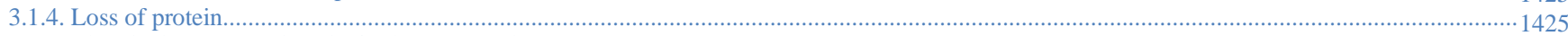

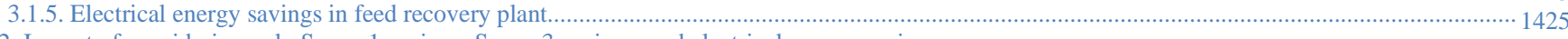

3.2. Impact of considering only Scope 1 savings, Scope 3 savings, and electrical energy savings...................................................................... 1425

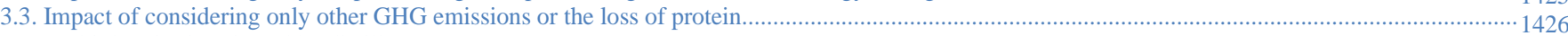

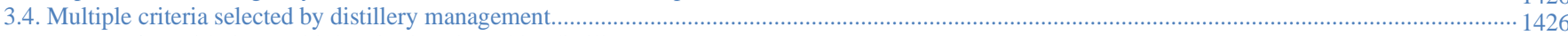

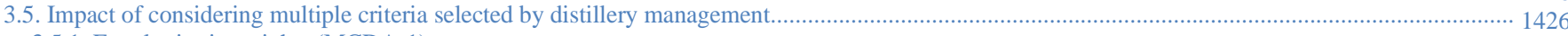

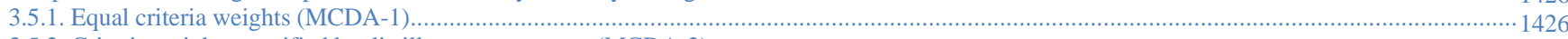

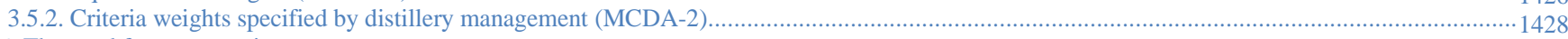

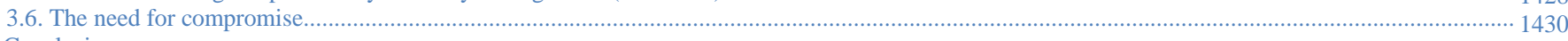

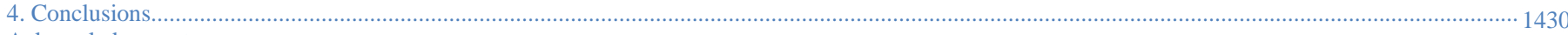

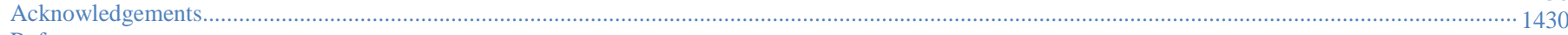

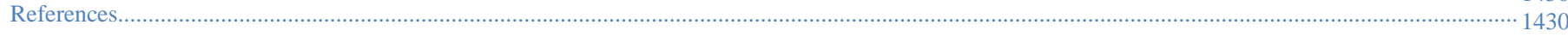

\begin{tabular}{|llll|}
\hline Abbreviations & & Abbreviations & \\
FB & Food and beverage & CSO & Central Statistics Office \\
ADG & Greenhouse gas & VIKOR & VlseKriterijumska Optimizacija I Kompromisno Resenje \\
MCDA & Anaerobic digestion & TOPSIS & $\begin{array}{l}\text { Technique for order of preference by similarity to ideal } \\
\text { solution }\end{array}$ \\
AHP & Multi criteria decision analysis & MCDA-1 & Multi criteria decision analysis scenario 1 \\
ELECTRE & Analytical hierarch process & MCDA-2 & Multi criteria decision analysis scenario 2 \\
CP & Compromise programming & wwt & Wet weight of material \\
FRP & Feeds recovery plant & & \\
DDG & Dried distillers' grains & Units & \\
BMP & Biochemical methane potential & twwt & Tonne wet weight of material \\
STP & Standard temperature and pressure & ktwwt & Kilo-tonne wet weight of material \\
N & Nitrogen & kt & Kilo-tonne \\
P & Phosphorous & MWhth & Megawatt hours of thermal energy \\
ED & Electoral division & GWh & Gigawatt hour \\
UFL & Unité Forragére Lait & t.km & Tonne-kilometre \\
\hline
\end{tabular}




\begin{tabular}{|c|c|c|c|c|c|}
\hline Nomenclature & Description & Unit & Nomenclature & Description & Unit \\
\hline$m C O_{2_{\text {Electricity }}}$ & $\begin{array}{l}\text { Scope } 2 \text { GHG emissions from } \\
\text { electricity use }\end{array}$ & $\mathrm{kgCO}_{2}$ & $m_{P_{\text {digestate }}}$ & $\begin{array}{l}\text { Mass of phosphorous contained in } \\
\text { digestate }\end{array}$ & $\mathrm{kgP}$ \\
\hline$T S$ & Total solids content of material & $\%$ wwt & $m_{\mathrm{CO}_{2} \text { Digestate Transport }_{\text {Th }}}$ & $\begin{array}{l}\text { Mass of } \mathrm{CO}_{2} \text { eq emissions } \\
\text { associated with digestate } \\
\text { transportation }\end{array}$ & $\mathrm{kgCO}_{2} \mathrm{eq}$ \\
\hline$V S$ & Volatile solids content of material & $\%$ wwt & $d_{E D}$ & $\begin{array}{l}\text { Distance from anaerobic digestion } \\
\text { plant to a parcel of land in an } \\
\text { electoral division over which } \\
\text { digestate is transported }\end{array}$ & $\mathrm{Km}$ \\
\hline$B M P$ & $\begin{array}{l}\text { Biochemical methane potential of } \\
\text { material }\end{array}$ & $\mathrm{LCH}_{4} / \mathrm{kgVS}$ & $S E_{C O 2_{\text {Digestate }_{\text {Transport }}}}$ & $\begin{array}{l}\text { Specific } \mathrm{CO}_{2} \text { eq emission intensity } \\
\text { of digestate transportation }\end{array}$ & $\mathrm{kgCO}_{2} \mathrm{eq} / \mathrm{t} . \mathrm{km}$ \\
\hline$\rho_{\mathrm{CH}_{4}}$ & Density of methane & $\mathrm{kg} / \mathrm{m}^{3}$ & $m_{C O 2{ }_{C A N} \text { Avoided }}$ & $\begin{array}{l}\text { Mass of greenhouse gas emissions } \\
\text { avoided when replacing calcium } \\
\text { ammonia nitrate fertiliser with } \\
\text { digestate }\end{array}$ & $\mathrm{kgCO}_{2} \mathrm{eq}$ \\
\hline$E_{\mathrm{CH}_{4}}$ & Energy content of methane & $\mathrm{MJ} / \mathrm{kg}$ & $m_{C O 2 P_{\text {Phos }} \text { Avoided }}$ & $\begin{array}{l}\text { Mass of greenhouse gas emissions } \\
\text { when replacing triple super } \\
\text { phosphate fertiliser with digestate }\end{array}$ & $\mathrm{kgCO}_{2} \mathrm{eq}$ \\
\hline$m_{i}$ & Mass of by-product ' $\mathrm{i}$ ' & kgwwt & $m_{\mathrm{CO} \text { Digestate }_{\text {Use }}}$ & $\begin{array}{l}\text { Mass of greenhouse gas emitted } \\
\text { when using digestate as a fertiliser }\end{array}$ & $\mathrm{kgCO}_{2} \mathrm{eq}$ \\
\hline$S_{i_{A D}}$ & $\begin{array}{l}\text { Share of by-product ' } i \text { ' used in an } \\
\text { anaerobic digestion plant }\end{array}$ & $\begin{array}{l}\text { Fraction of total } \\
\text { mass as a decimal }\end{array}$ & $\Delta G H G_{\text {Digestate }}$ & $\begin{array}{l}\text { Greenhouse gas emission saving } \\
\text { when replacing synthetic fertiliser } \\
\text { with digestate }\end{array}$ & $\mathrm{kgCO}_{2} \mathrm{eq}$ \\
\hline$X_{\text {Fugitive }}$ & $\begin{array}{l}\text { Fugitive methane emission from } \\
\text { the anaerobic digestion plant }\end{array}$ & $\begin{array}{l}\text { Fraction of total } \\
\text { methane produced } \\
\text { as a decimal }\end{array}$ & $d_{\text {Feeds }}$ & $\begin{array}{l}\text { Average transportation distance of } \\
\text { animal feeds produced by the } \\
\text { distillery }\end{array}$ & $\mathrm{Km}$ \\
\hline$m \mathrm{CO}_{2}$ eq $_{\text {Fugitive }}$ & $\begin{array}{l}\text { Mass of greenhouse gas } \\
\text { emissions associated with } \\
\text { fugitive methane emissions }\end{array}$ & $\mathrm{kgCO}_{2} \mathrm{eq}$ & $S E_{\mathrm{CO}_{2} \text { Transport }_{\text {Road }}}$ & $\begin{array}{l}\text { Specific greenhouse gas emissions } \\
\text { of road transportation of animal } \\
\text { feed by a truck }\end{array}$ & $\mathrm{kgCO}_{2} \mathrm{eq} / \mathrm{t} . \mathrm{km}$ \\
\hline$m_{\text {digestate }}$ total & $\begin{array}{l}\text { Mass of digestate remaining after } \\
\text { anaerobic digestion of by- } \\
\text { products }\end{array}$ & kgwwt & $d_{\text {mode }_{A F_{j}}}$ & $\begin{array}{l}\text { Transportation distance by mode for } \\
\text { alternative imported animal feed ' } \mathrm{j} \text { ' }\end{array}$ & $\mathrm{km}$ \\
\hline$X_{N_{i}}$ & Nitrogen content of by-product 'i' & $\mathrm{kgN} / \mathrm{kgwwt}$ & $d_{\text {ideal }}$ & $\begin{array}{l}\text { Deviation of result from utopian } \\
\text { value }\end{array}$ & unitless \\
\hline$X_{P_{i}}$ & $\begin{array}{l}\text { Phosphorous content of by- } \\
\text { product ' } i \text { ' }\end{array}$ & $\mathrm{kgP} / \mathrm{kgwwt}$ & & & \\
\hline
\end{tabular}

\section{Introduction}

Globally, the food and beverage (FB) sector emits $0.75 \%$ of energy-related greenhouse gas (GHG) emissions (United Nations Framework Convention on Climate Change, 2019), primarily from the combustion of gaseous fossil fuels. Industrial GHG emissions need to reduce by $80 \%$ through reduced demand, increased efficiency, electrification, decarbonising remaining non-electric fuels, and carbon capture and sequestration (Rogelj et al., 2018). Certain processes in the FB sector (evaporation, distillation, and drying) are difficult to electrify due to the higher temperatures required in these processes (IEA, 2018); thus, decarbonisation of these processes may benefit from the use of renewable gaseous fuels. 
Anaerobic digestion (AD) of biodegradable by-products can produce biogas, a renewable gaseous fuel that is a mixture of methane and carbon dioxide. A detailed description of the process can be found in (Murphy and Thamsiriroj, 2013). The production of biogas from biodegradable materials has been highlighted as a key component of the circular economy allowing for the recovery of energy and biological nutrients (Ellen MacArthur Foundation, 2013). Globally, biogas is predicted to play a significant role in future energy systems and could contribute up to $20 \%$ of modern bioenergy supply in 2040 (IEA, 2020). A plethora of prior work has assessed the energy resource of biogas at a regional level. Examples include the biogas resource derived from organic waste in the EU (Lorenz et al., 2013), the resource associated with agricultural wastes in China (Yan et al., 2021), and the energy resource associated slaughterhouse wastes in the USA (Wang et al., 2018).

Advantages of integrating $\mathrm{AD}$ with installations in the $\mathrm{FB}$ sector include: improved management of by-products, reducing Scope 1 GHG emissions by replacing natural gas consumption, producing high temperature renewable heat, increased energy security, and the recycling of nutrients to land in the form of digestate (Fagerström et al., 2018). Nutrient recycling can reduce fertiliser consumption in agriculture, thus reducing the indirect (Scope 3) GHG emissions of facilities in the FB sector. A description of Scope 1 (direct) and Scope 3 (indirect) GHG emissions can be found in (WBCSD and WRI, 2004). Drawbacks of integrating AD into the FB sector include reduced animal feed production as outlined by Lindkvist et al. (2019) and Leinonen et al. (2018), which could be seen as economically or environmentally detrimental and may result in public opposition (Nevzorova and Kutcherov, 2019). AD plant development can be hindered by concerns relating to traffic movements required for digestate management (Capodaglio et al., 2016) which are exasperated as plant size increases. Management costs associated with the application of digestate on land owned by farmers who supply raw materials to the FB sector also increase with the mass of digestate to be managed (Dahlin et al., 2015). Some or all of these drawbacks also apply to AD projects which use other feedstock such as organic wastes, animal manures, and dedicated energy crops.

In the FB sector Lindkvist et al. (2019) assessed the conversion of byproducts from the FB sector to biogas which accounted for economic, energy, and environmental performance. Lorenz et al. (2013) assessed the potential energy resource associated with processing biodegradable wastes in the EU, including by-products from the brewing industry. Research into the integration of $\mathrm{AD}$ and distilleries has been conducted since the 1970s (Pipyn and Verstraete, 1979). An overview of 28 prior works is provided in O'Shea et al. (2020). Kang et al. (2020) assessed GHG emission reductions as well as the potential replacement of fertilizer using digestate when digesting by-products of whiskey production. Leinonen et al. (2018) considered GHG emission reductions, accounted for the replacement of fertilizer with digestate, and calculated the potential loss of animal feed production. The logistical aspects of digestate use were considered by Drosg et al. (2008 and 2013) and Weber and Stadlbauer (2017). O'Shea et al. (2020) determined that Scope 1 and Scope 3 GHG emissions could be reduced if an AD plant processing all by-products available was integrated into a large distillery. However, GHG emissions from potentially imported animal feeds were found to be substantial. No attempt was made at determining the "optimal" share of by-products to use in an AD plant to balance the positive and negative aspects of $\mathrm{AD}$ integration.

Balancing the positive and negative aspects of renewable energy projects can be achieved through the use of multi-criteria decision analysis (MCDA) techniques as outlined by Campos-Guzmán et al. (2019) and Siksnelyte et al. (2018). Several MCDA techniques can be applied such as: Simple Weighted Sum, the Analytical Hierarch Process (AHP), Elimination and Choice Translating Reality (ELECTRE), and Compromise Programming (CP). Reviews of these methods and their application to renewable energy projects can be found in the literature (Kumar et al., 2017; Mardani et al., 2017). The authors have been unable to source any literature which uses MCDA to balance the benefits and drawbacks of integrating $\mathrm{AD}$ into a plant in the FB sector by selecting the optimal blend of by-products to use.

This work aims to address this knowledge gap via four objectives. Firstly, assess the energy resource and potential Scope 1 GHG emissions saving associated with $\mathrm{AD}$ of differing portions of distillery by-products. Simultaneously the production of digestate, potential fertiliser replacement, and Scope 3 GHG emissions saving based on the use of different portions of distillery by-products in an AD plant will be calculated. The reduction in animal feed production, potential imported animal feeds, and associated GHG emissions when different shares of by-products are used in an AD plant will be determined. Finally, MCDA (specifically CP) will be used to assess which combination of distillery by-products should be used in an AD plant to balance the positive and negative aspects of $\mathrm{AD}$ integration.

The analysis conducted in this work is applied to a large distillery in the Republic of Ireland, which is a major player in the whiskey and distilled spirits industry globally. The methodology developed herein can be applied to any other facility in the FB sector globally to aid in a more nuanced assessment of $\mathrm{AD}$ integration.

\section{Materials and Methods}

The calculations conducted herein are split across three main areas; biogas production, digestate production, and animal feed production when differing shares of distillery by-products are used in an AD plant. A flowchart outlining the calculation procedure is provided in Figure 1.

\subsection{Distillery and operations}

The period of production assessed in this work (May 2018 to May 2019) resulted in the production of approximately 61.126 million litres of original alcohol at the distillery. Draff, thick stillage, and thin stillage are byproducts produced by the distillery. The by-products are processed in a feeds recovery plant (FRP) to produce three animal feed products: wet grains, dried distillers' grains (DDG), and syrup. Details are provided in Table 1.

The mass of $\mathrm{CO}_{2}$ emitted from the combustion of natural gas is based on a $\mathrm{CO}_{2}$ emission intensity of natural gas $\left(S E_{\mathrm{CO}_{2} \text { Natural Gas }}\right)$ of 201 $\mathrm{kgCO}_{2} / \mathrm{MWh}_{\text {th }}$ (EPA, 2019). Natural gas combustion accounts for over $99 \%$ of Scope 1 GHG emissions arising from the distillery. The distillery currently sources all electricity from renewable sources, as such, the Scope $2 \mathrm{GHG}$ emissions associated with this electricity $\left(\mathrm{mCO}_{2_{\text {Electricity }}}\right)$ are zero. Energy consumption is given in Table 2.

Scope 3 emissions are classified into 15 categories according to reporting standards (WBCSD and WRI, 2013a), 9 categories are used by the distillery for classifying Scope 3 emissions (See Appendix A). The alteration of Scope 3 GHG emissions at the distillery by an AD plant treating by-products will be outlined in the following sections.

\subsection{Biogas production from by-products}

\subsubsection{By-product characteristics}

By-product samples were sourced from the distillery and characterised in terms of their total solids content $\left(T S_{i}\right)$, and volatile solids content $\left(V S_{i}\right)$ (Allen et al., 2015). Experimental assays to determine the biochemical methane potential $(B M P)$ were conducted in triplicate following the methods detailed in prior works (Allen et al., 2015; Wall et al., 2013). The $T S$ content, $V S$ content, and $B M P$ values for each by-product are given in Table 3 .

\subsubsection{Biogas production}

Gross energy production from AD of by-products (Eq. 1) is calculated using the biochemical methane potential of each by-product $\left(B M P_{i}\right)$, an assumed digestion efficiency ( $\eta_{\text {Digestion }}$ ) of $80 \%$ in continuous operations, methane density $\left(\rho_{\mathrm{CH}_{4}}\right)$ of $0.714 \mathrm{~kg} / \mathrm{m}^{3}$ at Standard Temperature and Pressure (STP), an energy content of methane $\left(E_{\mathrm{CH}_{4}}\right)$ of $50 \mathrm{MJ} / \mathrm{kg}$, the mass of each by-product available $\left(m_{i}\right)$, the share of each by-product used in an AD plant $\left(S_{i_{A D}}\right)$, and the volatile solids content of each by-product $\left(V S_{i}\right)$. Division by 3,600 facilitates conversion to $\mathrm{MWh}_{\mathrm{th}}$.

$$
E_{\text {biogas }_{\text {Gross }}}=\frac{\left(\frac{\eta_{\text {Digestion }}}{100} * \sum_{i=1}^{3} S_{i_{A D}} * m_{i} * \frac{V S_{i}}{100} * B M P_{i}\right)}{1000} * \rho_{C_{H_{4}}} * E_{C H_{4}} \text { Eq.1 }
$$




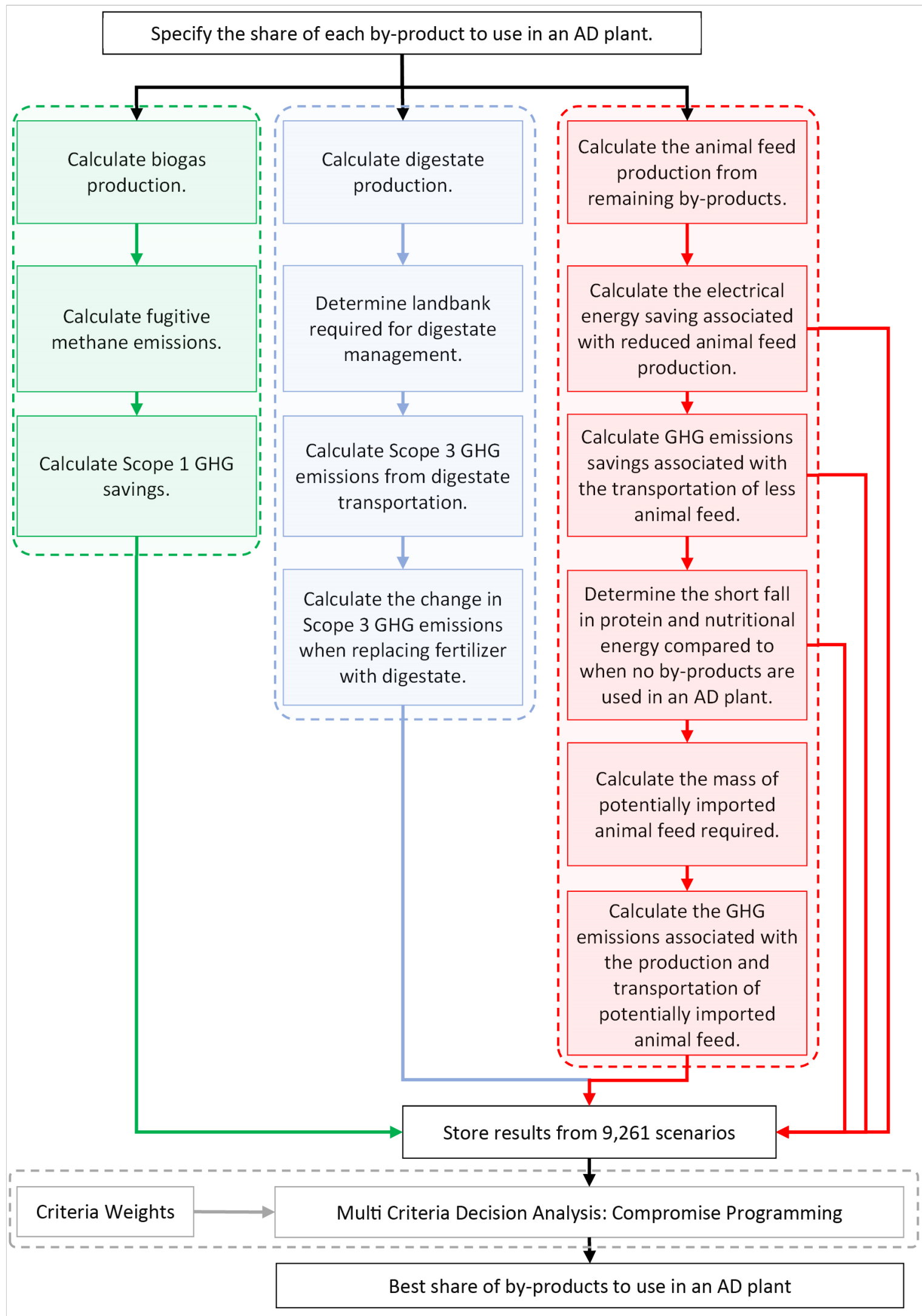

Fig. 1. Calculation flowchart. AD: Anaerobic Digestion. GHG: Greenhouse Gas. 
Table 1.

By-product and feed product mass. 'ktwwt': Kilo-tonne of Wet Weight of Material. 'DDG': Dried Distillers' Grains.

\begin{tabular}{|c|c|c|c|}
\hline Parameter & Symbol & $\begin{array}{c}\text { Mass } \\
\text { (ktwwt/a) }\end{array}$ & Description \\
\hline Draff & $m_{\text {Draff }}$ & 46.7 & $\begin{array}{l}\text { Residual solids following the brewing } \\
\text { of malted and un-malted barley to } \\
\text { produce wort. }\end{array}$ \\
\hline Thick Stillage & $m_{\text {Thick }}$ & 277.5 & $\begin{array}{l}\text { Liquid remaining after the distillation } \\
\text { of pot ale (a residual liquid remaining } \\
\text { after the initial distillation of } \\
\text { fermented wort) }\end{array}$ \\
\hline Thin Stillage & $m_{\text {Thin }}$ & 322.8 & $\begin{array}{l}\text { Solid-liquid mixture remaining after } \\
\text { the distillation of maize in a } \\
\text { continuous distillation column. }\end{array}$ \\
\hline Wet Grain & $m_{\text {Wet Grain }}$ & 62.776 & $\begin{array}{l}\text { A mixture of draff, the solid portion } \\
\text { of thick stillage, and syrup }\end{array}$ \\
\hline DDG & $m_{D D G}$ & 12.806 & $\begin{array}{l}\text { A mixture of wet grains and syrup } \\
\text { which is dried }\end{array}$ \\
\hline Syrup & $m_{\text {Syrup }}$ & 41.794 & $\begin{array}{l}\text { Produced from the evaporation of } \\
\text { water from thin stillage and the liquid } \\
\text { portion of thick stillage }\end{array}$ \\
\hline
\end{tabular}

Table 2.

Distillery annual energy consumption. subscript 'th' corresponds to thermal energy. Subscript 'e' corresponds to electrical energy.

\begin{tabular}{lccc}
\hline Parameter & Symbol & Unit & Value \\
\hline Total Natural Gas Demand & $E_{\text {Natural Gas }}$ & $\mathrm{GWh}_{\mathrm{th}} / \mathrm{a}$ & 229 \\
Steam Demand of Feeds Recovery Plant & $E_{\text {Thermal }_{\text {Feeds }}}$ & $\mathrm{GWh}_{\mathrm{th}} / \mathrm{a}$ & 8.7 \\
$\mathrm{CO}_{2}$ eq from Natural Gas Combustion & $m$ O $_{2_{\text {Natrual Gas }}}$ & $\mathrm{tCO}_{2} \mathrm{eq} / \mathrm{a}$ & 45,975 \\
Total Electricity Consumption & $E_{\text {Electrical }_{\text {Distillery }}}$ & $\mathrm{GWh}_{\mathrm{d}} / \mathrm{a}$ & 42 \\
Electricity Demand of Feeds Recovery Plant & $E_{\text {Electrical }_{\text {Feeds }}}$ & $\mathrm{GWh}_{\mathrm{c}} / \mathrm{a}$ & 7.9 \\
\hline
\end{tabular}

\subsubsection{Fugitive methane emissions}

This work assumes fugitive methane emissions $\left(X_{\text {Fugitive }}\right)$ from the $\mathrm{AD}$ plant of $2 \%$ (see Appendix $\mathrm{C}$ for details). The total mass of $\mathrm{CO}_{2}$ eq emitted as a result of fugitive emissions $\left(\mathrm{mCO}_{2} \mathrm{eq}_{\mathrm{Fugitive}}\right)$ is calculated using Equation 3 and a global warming potential of 25 for methane ( $O$ 'Shea et al., 2020). Fugitive emissions will contribute to Scope 1 GHG emissions of the distillery, minimisation of fugitive emissions will ensure greater Scope 1 GHG emissions saving.

$$
\begin{gathered}
m \mathrm{CO}_{2_{\text {eq }}}=\left(\eta_{\text {Digestion }} * \sum_{i=1}^{3} S_{i_{A D}} * m_{i} * V S_{i} * B M P_{i}\right) * \rho_{C H_{4}} \\
* X_{\text {Fugitive }} * 25
\end{gathered}
$$

\subsection{Digestate production}

The total mass of digestate $\left(m_{\text {digestate }_{\text {total }}}\right)$ produced can be calculated as per Equation 4.

$m_{\text {digestate }_{\text {total }}}=\sum_{i=1}^{3} S_{i_{A D}} * m_{i} *\left(1-\eta_{\text {Digestion }} * V S_{i}\right)$

The nitrogen $(\mathrm{N})$ and phosphorous $(\mathrm{P})$ content of the digestate was estimated based on feedstock $\mathrm{N}\left(X_{N_{i}}\right)$ and $\mathrm{P}\left(X_{P_{i}}\right)$ content (Table 3$)$. The total mass of nitrogen $\left(m_{N_{\text {digestate }}}\right)$ and phosphorous $\left(m_{P_{\text {digestate }}}\right)$ leaving the $\mathrm{AD}$ plant in digestate are assumed to be equal to the total mass of nitrogen and phosphorous contained in the by-products added to the $\mathrm{AD}$ plant calculated according to Equation 5 and Equation 6, respectively.

$$
\begin{aligned}
& m_{N_{\text {digestate }}}=\sum_{i=1}^{3} S_{i_{A D}} * m_{i} \cdot X_{N_{i}} \\
& m_{P_{\text {digestate }}}=\sum_{i=1}^{3} S_{i_{A D}} * m_{i} \cdot X_{P_{i}}
\end{aligned}
$$

Table 3.

By-product properties. 'TS': Total Solids Content. 'VS': Volatile Solids Content. 'BMP': Biochemical Methane Potential. 'N': Nitrogen. 'P': Phosphorous. '\%wwt': Percentage of Wet Weight of Material

\begin{tabular}{lcccccc}
\hline By-product & $\begin{array}{c}\text { TS } \\
\mathbf{\% w w t}\end{array}$ & $\begin{array}{c}\text { VS } \\
\mathbf{\% w w t}\end{array}$ & $\begin{array}{c}\text { BMP } \\
\mathbf{L C H} / \mathbf{k g V S}\end{array}$ & $\begin{array}{c}\text { Methane Yield } \\
\mathbf{L C H}_{\mathbf{4}} / \mathbf{k g w w t}\end{array}$ & $\begin{array}{c}\text { Nitrogen } \\
(\mathbf{g N / k g w w t )}\end{array}$ & $\begin{array}{c}\text { Phosphorous } \\
(\mathbf{g P / k g w w t})\end{array}$ \\
\hline Draff & 27.6 & 26.5 & $330 \pm 2.2$ & $87.4 \pm 0.6$ & 13.76 & 1.76 \\
Thin Stillage & 3.9 & 3.5 & $494.6 \pm 41.0$ & $17.4 \pm 1.4$ & 1.60 & 0.33 \\
Tick Stillage & 8.8 & 8.2 & $502.6 \pm 42.7$ & $41.4 \pm 3.5$ & 3.68 & 0.91 \\
\hline
\end{tabular}

The net energy $\left(E_{\text {Biogas }}{ }_{\text {Net }}\right)$ production of the AD plant was determined by subtracting the total thermal energy demand of the $\mathrm{AD}$ plant as outlined by the authors (O'Shea et al., 2020) and are contained in Appendix B.

The mass of $\mathrm{CO}_{2}$ eq avoided by using biogas to replace natural gas $\left(\mathrm{mCO}_{2_{\text {Biogas }}}\right)$ is calculated assuming a carbon intensity of natural gas of $\left(S E_{\mathrm{CO}_{\text {Natural Gas }}}\right) 201 \mathrm{kgCO}_{2} / \mathrm{MWh}$ as per Equation 2.

$m_{\mathrm{CO}_{2_{\text {Biogas }}}}=E_{\text {Biogas }_{\text {Net }}} * S E_{\mathrm{CO}_{\text {Natural Gas }}}$

Using biogas would reduce Scope $1 \mathrm{GHG}$ emissions at the distillery site and would also reduce the Scope $3 \mathrm{GHG}$ emissions associated with the upstream production and transportation of natural gas outlined (O'Shea et al., 2020).

\subsubsection{Calculating the landbank required for spreading of digestate}

The land area required for digestate spreading was calculated in accordance with S.I. 605 of 2017 as outlined in prior work by the authors (O'Shea et al., 2020) and is provided in Appendix D for completeness. The $\mathrm{CO}_{2} \mathrm{eq}$ emissions associated with the transportation of digestate $\left(m_{\mathrm{CO}{ }_{\text {Digestate }} \text { Transport }}\right)$ to each Electoral Division (ED) was calculated based on the mass of digestate sent to each ED $\left(m_{\text {Digestate }_{E D}}\right)$ and the distance to each $\mathrm{ED}\left(d_{E D}\right)$ as per Equation 7. The specific $\mathrm{CO}_{2} \mathrm{eq}$ emissions associated with the transportation of digestate $\left(S E_{\mathrm{CO}_{\text {Digestate }}}\right.$ Transport $)$ to farmland was taken to be $0.19 \mathrm{kgCO}_{2} \mathrm{eq} / \mathrm{t} . \mathrm{km}$ based on prior work by the authors (O'Shea et al., 2020). 
$m \mathrm{CO}_{2_{\text {Digestate }_{\text {Tranport }}}}=m_{\text {Digestate }_{E D}} * d_{E D} * S E_{\mathrm{CO}_{2} \text { Digestate }_{\text {Transport }}}$

The GHG emissions associated with the transportation of digestate will contribute to Scope $3 \mathrm{GHG}$ emissions. The specific $\mathrm{CO}_{2}$ eq emissions

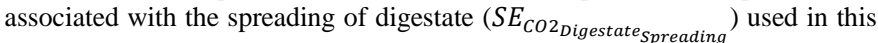
work is $1.15 \mathrm{kgCO} \mathrm{eq}_{\mathrm{wwt}}$ based on a review of work by (Berglund and Börjesson, 2006; Nemecek and Kagi, 2007; Korres et al., 2010; Pöschl et al., 2010; Foley et al., 2011; Nguyen et al., 2011; Rehl and Müller, 2011; Dieterich et al., 2014; Lijó et al., 2014; McAuliffe et al., 2017).

As indicated in prior work by the authors (O'Shea et al., 2020), the potential land bank, truck movements, and storage volumes required for digestate management may be substantial. Therefore, the use of digestate processing is considered a mandatory element of the AD project. However, this work does not consider the impact of digestate processing techniques as the processing technique to be used has not yet been decided. The landbank, transportation energy consumption, and associated GHG emissions resulting from the management of the whole digestate will be considered in this work

\subsubsection{Calculating the impact of digestate use on GHG emissions associated} with barley cultivation

Digestate can be applied to land used for the cultivation of barley that is subsequently used in the distillery and could reduce Scope 3 GHG emissions of the distillery. The mass of synthetic nitrogen and phosphorous fertiliser that can be replaced by digestate is outlined in Appendix E.

Direct and indirect $\mathrm{N}_{2} \mathrm{O}$ emissions associated with the application of nitrogen fertiliser to agricultural land are calculated according to the report by Duffy et al. (2020) in line with IPCC guidelines (Dong et al., 2006;
Hergoualc'h et al., 2019). A detailed description of these calculations is given in Appendix F. An example of the calculation to determine the mass of synthetic phosphorous fertiliser replaced by digestate and the avoided GHGs is given Appendix $\mathbf{E}$ and in Appendix F, respectively. An example calculation of the GHG emissions associated with the use of digestate as a source of nitrogen fertiliser on land used for barley cultivation is shown in Box F-3.

Replacing calcium ammonia nitrate (CAN) commonly used nitrogen fertiliser with digestate results in GHG emissions savings ( $\left.m_{\mathrm{CO} 2 \mathrm{CAN}_{\mathrm{N}}}\right)$. Replacing triple super phosphate, a commonly used source of phosphorous, with digestate also results in GHG emission savings ( $\left.m_{C O 2_{P h o s}}{ }_{\text {Avoided }}\right)$. Using digestate as a fertiliser to cultivate barley will result in the emission of some GHGs ( $m_{\mathrm{CO}^{2} \text { Digestate }_{\text {Use }}}$ ). Combining the GHG emissions avoided when replacing CAN and triple super phosphate, with the emissions arising from the use of digestate allows for the potential change in GHG emissions $\left(\Delta G H G_{\text {Digestate }}\right)$ to be calculated via Equation 8. This will impact the Scope 3 GHG emissions of the distillery (if the barley grown is used in the distillery).

$$
\begin{aligned}
& \Delta G H G_{\text {Digestate }}=m_{\mathrm{CO}_{C_{C A N} \text { Avoided }}}+m_{\text {CO2 }_{\text {Phos }} \text { Avoided }} \\
& \text { - } m_{\mathrm{CO}_{2} \text { Digestate Use }}
\end{aligned}
$$

\subsection{Production of animal feed}

The production of animal feed was calculated based on a mass balance of the FRP, an indicative flowchart of the FRP is shown in Figure 2. Altering the mass of each by-product used in the FRP will alter the mass

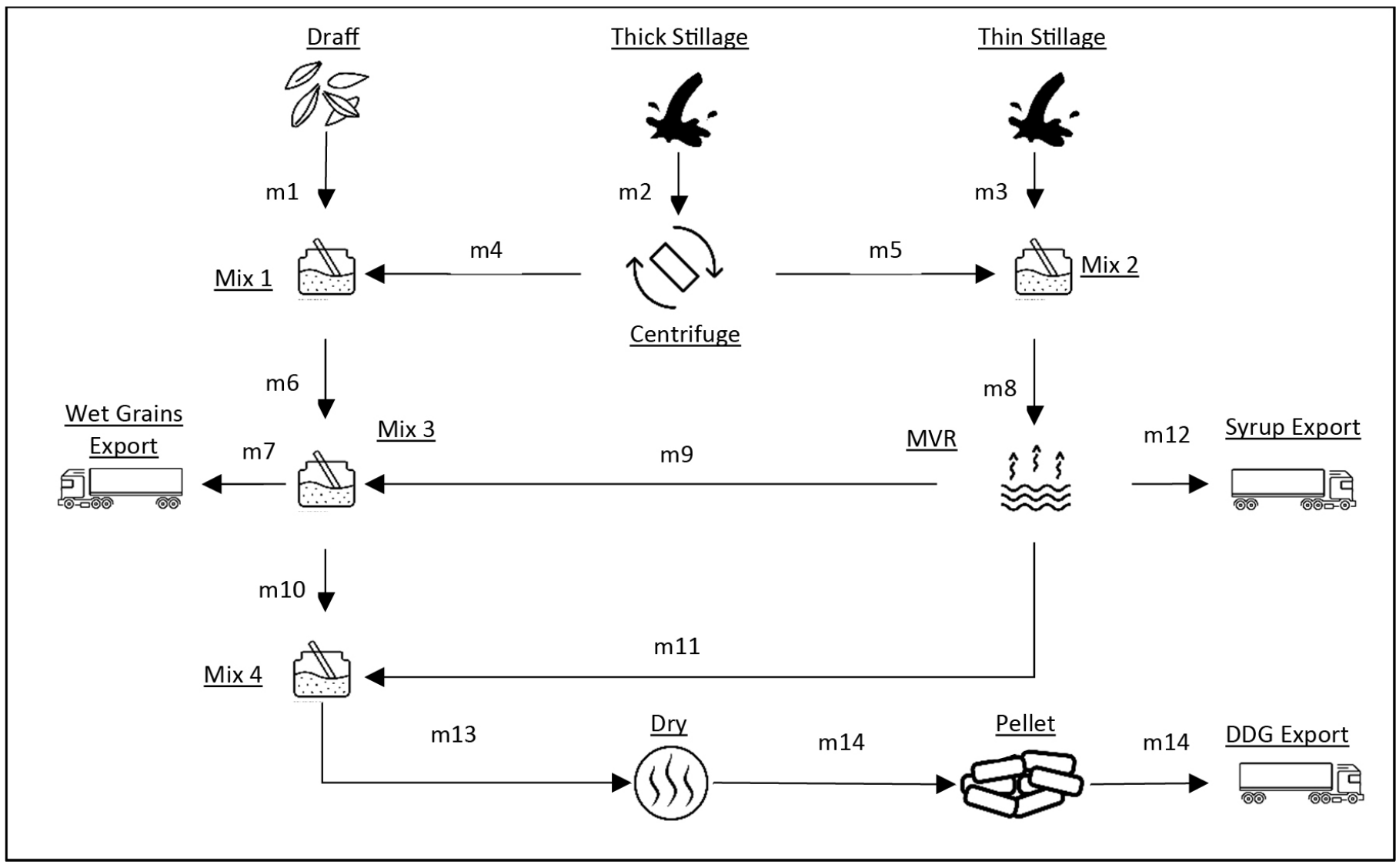

Fig. 2. Feeds recovery plant layout. 'DDG': Dried Distillers' Grains. 'MVR': Mechanical Vapour Recompression. 'm1': Draff. 'm2': Thick Stillage. 'm3': Thin Stillage. 'm4': Cake Maize from

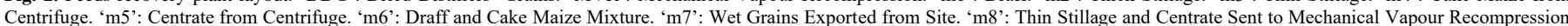

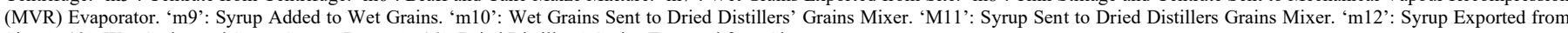
Site. 'm13': Wet Grains and Syrup Sent to Dryer. 'm14': Dried Distillers' Grains Exported from Site. 
and composition of the resulting feed products (wet grains, DDG, and syrup). A detailed description of the equations governing the feeds recovery plant is given in Appendix G. Based on the share of by-products sent to a potential AD plant the mass of; wet grains $(m 7)$, DDG $(m 14)$, and syrup $(m 12)$, along with their respective nutritional energy content (Unité Forragére Lait (UFL)) and protein content can be calculated by solving the mass balances outlined in Appendix G.

\subsection{Feeds recovery plant energy consumption}

Using by-products in an $\mathrm{AD}$ plant will alter the thermal and electrical energy consumption of the FRP. The energy consumption of the FRP is calculated using models detailed in Appendix H. Reduced output of the FRP will lower natural gas consumption at the distillery and will reduce Scope 1 GHG emissions as outlined in Appendix I. Reduced throughput of distillery byproducts in the FRP will also lower electrical energy consumption; calculation of the electrical energy savings associated with reduced FRP throughput are is detailed in Appendix I.

\subsubsection{Transportation of feed products}

The $\mathrm{CO}_{2} \mathrm{eq}$ emissions from animal feed product transportation $\left(\mathrm{mCO}_{2_{\text {Feed }} \text { Transport }}\right)$ are calculated based on the total mass of feed products produced $\left(m_{\text {Feeds }}\right)$, an average transportation distance $\left(d_{\text {Feeds }}\right)$ of $98 \mathrm{~km}$, and a specific $\mathrm{CO}_{2}$ eq emission of $225 \mathrm{gCO}_{2}$ eq/t.km for goods transportation by truck $\left(S E_{\text {CO2 }_{\text {Transport }_{\text {Road }}}}\right)$ as per Equation 9 adapted from (WBCSD and WRI, 2013b).

$m C O_{\text {Feed }_{\text {Tranport }}}=m_{\text {Feeds }} * d_{\text {Feeds }} * S E_{\mathrm{CO}_{\text {Transport }} \text { Road }}$

Transportation of feed products is not within the value chain of the distillery, and as such these emissions do not fall within Scope 1, Scope 2, or Scope 3 and are classified as "other emissions".

\subsection{Replacement of animal feed}

Based on the mass, UFL content, and protein content of each feed product currently produced and the feed products produced when by-products are used in an AD plant, it is possible to calculate the difference in total UFL and protein produced. The mass of alternative feeds required to replace this difference can thus be calculated. Replacement of animal feeds produced at the distillery with imported animal feeds was assessed as this is seen as a "worst case" scenario which would result in the highest GHG emissions. Data that compared indigenously grown animal feed to imported animal feed indicates that from 2014-2018 2,332 kt (39\%) of feed was grown in Ireland, compared to 3,707 kt (62\%) of imported feed during the same period from (Wallace, 2020).

Imported replacement feeds assessed (distillers grains, maize gluten feed, soybean meal, and soyhulls), each has their own UFL and protein content as per Table 4. An optimisation model with the goal of calculating the minimum required mass of each alternative replacement feed to make up the difference in energy (UFL) and protein was developed. A description of the model is given in Appendix J.

\subsubsection{GHG emissions associated with imported replacement animal feed production}

Source countries of imported animal feeds were based on data acquired from the Irish Central Statistics Office (CSO), a detailed description is provided in Appendix K. GHG emissions associated with the production of imported animal feed are based on the mass of each feed required and the associated production emissions intensities sourced from the Global Feed Lifecycle Institute database of animal feed production (Blonk and Paassen, 2018). Details on the calculation method are also provided in Appendix $\mathbf{K}$. The GHG emissions associated with potentially imported animal feed are not within the boundary of Scope 1, Scope 2, or Scope 3 emissions, as such they are classified as "other emissions".
Table 4.

Composition of replacement feeds. 'UFL': Unité Forragére Lait. 'wwt': Wet Weight of Material.

\begin{tabular}{lccl}
\hline Feed & $\begin{array}{c}\text { Crude Protein } \\
\text { g/kgwwt }\end{array}$ & $\begin{array}{c}\text { Energy } \\
\text { UFL/kgwwt }\end{array}$ & Imported Feed \\
\hline Distillers Grains & 266.1 & 1.0324 & $\begin{array}{l}\text { Brewing or distilling dregs } \\
\text { and waste }\end{array}$ \\
Maize Gluten Feed & 203.3 & 0.8996 & $\begin{array}{l}\text { Residues from the } \\
\text { manufacture of starch from } \\
\text { maize of a kind used in } \\
\text { animal feeding }\end{array}$ \\
Soya Bean Meal & 481.2 & 1.0195 & $\begin{array}{l}\text { Oilcake and other solid } \\
\text { residues resulting from the } \\
\text { extraction of soya-bean oil }\end{array}$ \\
Soya Hulls & 104.6 & 0.8878 & $\begin{array}{l}\text { Oilcake and other solid } \\
\text { residues resulting from the } \\
\text { extraction of soya-bean oil }\end{array}$ \\
\hline
\end{tabular}

\subsubsection{GHG emissions associated with transportation of imported replacement animal feed}

Transportation emissions of imported animal feeds are based on distances of each imported feed by mode of transportation $\left(d_{\text {mode }_{A F_{j}}}\right)$, as outlined in Appendix L. The emissions arising from the transportation of potentially imported animal feed are also classified as "other emissions".

\subsection{Digestate logistics}

Digestate must be stored until it can be spread at the optimal times for crop uptake, as outlined by Plana and Noche (2016) and Logan and Visvanathan (2019). Digestate is to be used on land to cultivate barley that will then be used by the distillery to mitigate Scope 3 GHG emissions. In prior work by the authors, the volume of digestate storage required could be substantial if using a large portion of distillery by-products in an AD plant (O'Shea et al., 2020). The use of digestate processing to reduce storage volume and transportation requirements is seen as a necessary component of an $\mathrm{AD}$ plant processing distillery by-products by distillery management. Therefore, the storage volumes and truck movements required for digestate management are not considered in this work as the optimum digestate processing method has not been finalised.

\subsection{Multi criteria decision analysis (MCDA)}

\subsubsection{Compromise programming}

The MCDA technique used in this work is CP, developed by Zelany (1974) and Zeleny (1976). CP is based on the identification of an "ideal" solution that is generally infeasible, the identification of a "nadir" solution, and uses these to aid in the selection of a feasible "optimal" solution that is closest to the ideal. The CP method was used in this work as it is the basis for MCDA techniques such as VlseKriterijumska Optimizacija I Kompromisno Resenje (VIKOR) and Technique for Order of Preference by Similarity to Ideal Solution (TOPSIS). The concept of determining which solution is closest to an ideal is relatively simple to understand and has been used by scholars since the early days of MCDA (Yu, 1985). CP has been used extensively in a range of fields, including agricultural planning (Romero et al., 1987), river basin development (Duckstein and Opricovic, 1980), the improvement of building energy efficiency (Diakaki et al., 2008), energy management in microgrids (Panwar et al., 2017; Sandgani and Sirouspour, 2018), forest management (de Sousa Xavier et al., 2015), the interaction between variable renewable generation technologies (Canales et al., 2020), and sustainability assessment (Dorini et al., 2011) amongst others. A detailed description of the CP methodology used in this work is given in Appendix M. There is technically an infinite number of by-product combinations that could be used in an AD plant. In order to present real world results, different scenarios are generated by varying the share of each by-product used in an AD plant from 0 to $100 \%$ (in increments 
Table 5.

Justification for criteria selection. 'MCDA': Multi Criteria Decision Analysis. 'GHG': Greenhouse Gas. 'FRP': Feeds Recovery Plant. 'AD': Anaerobic Digestion.

\begin{tabular}{|c|c|c|c|c|}
\hline Criterion & Objective & Include MCDA & Weight & Justification \\
\hline Scope 1 Savings & Maximise & Yes & 0.3213 & Reducing Scope 1 GHG emissions is a key priority of distillery management. \\
\hline Scope 3 Savings & Maximise & Yes & 0.3213 & $\begin{array}{l}\text { Reducing Scope } 3 \text { GHG emissions is a high-level target of distillery management. Using digestate as a } \\
\text { fertiliser for the cultivation of barley that is consumed by the distillery can reduce Scope } 3 \text { GHG emission. }\end{array}$ \\
\hline Other GHG Emissions & Minimise & Yes & 0.1325 & $\begin{array}{l}\text { Emissions associated with the production and transportation of potentially imported animal feed were selected } \\
\text { owing to concerns regarding the potential global impact of reducing animal feed production when by-products } \\
\text { are used in an AD plant. }\end{array}$ \\
\hline Loss of Protein Production & Minimise & Yes & 0.1953 & $\begin{array}{l}\text { Included owing to concerns in relation to the potential negative impact that an } \mathrm{AD} \text { plant could have on the } \\
\text { supply of high-quality plant derived animal feeds to the local agricultural sector. }\end{array}$ \\
\hline Electricity Savings in FRP & Maximise & Yes & 0.0296 & $\begin{array}{l}\text { Electrical energy savings in the feed recovery plant (FRP) were selected as the FRP is one of the largest } \\
\text { consumers of electricity in the distillery. }\end{array}$ \\
\hline Digestate Production & Minimise & No & N/A & $\begin{array}{l}\text { The mass of digestate produced by the anaerobic digestion of distillery by-products can potentially be large. } \\
\text { As a result, the use of digestate processing is seen as a mandatory element of any AD project at the distillery. } \\
\text { This will reduce the logistical issues of storage and transportation associated with digestate management. As } \\
\text { such, the production of digestate is not considered in this analysis. }\end{array}$ \\
\hline Total GHG Emissions & Maximise & No & N/A & $\begin{array}{l}\text { Total GHG emissions savings (summation of Scope } 1 \text {, Scope } 3 \text {, and other GHG emissions) is not included in } \\
\text { the MCDA as these emissions are not strictly additive as companies have control over which of categories of } \\
\text { emissions are to be included in the reporting of Scope } 3 \text { GHG emissions. }\end{array}$ \\
\hline Loss of Nutritional Energy & Minimise & No & N/A & $\begin{array}{l}\text { The loss of nutritional energy is not included in the MCDA as distillery management indicated a greater } \\
\text { concern in relation to the loss of protein. }\end{array}$ \\
\hline Financial Performance & N/A & No & N/A & $\begin{array}{l}\text { The financial performance of an AD plant processing by-products was not included in the MCDA owing to a } \\
\text { lack of reliable data on the costs associated with construction of an AD plant at numerous different scales } \\
\text { depending on the share of by-product use. }\end{array}$ \\
\hline
\end{tabular}

of 5\%) resulting in a total of 9,261 different solutions generated in this work.

\subsubsection{Selection of criteria included in multi criteria decision analysis}

Criteria included in the $\mathrm{CP}$ analysis were determined following discussions with distillery management (Table 5). The results of the analysis in this work will be assessed with respect to each of these criteria individually to ascertain the differences that arise when choosing different criteria. The distillery management determined that the following criteria should be included in the analysis: Scope 1 GHG emissions, Scope 3 GHG emissions, other GHG emissions (from potentially imported animal feed), loss of protein production, and electricity savings in the feeds recovery plant. Initial $\mathrm{CP}$ analysis was conducted assuming equal importance for all criteria selected (MCDA-1), this would result in each criterion receiving a "weight" of 0.2 (five criteria were considered in MCDA-1).

A workshop was held with distillery management to ascertain the relative degree of importance ("Weights") of each criterion selected using the AHP method (Saaty, 1990). The relative degrees of importance of the selected criteria are included in Table 5. The consistency ratio obtained during the AHP process was 0.09 , which indicates that the pairwise comparisons made by distillery management were consistent (Saaty, 1990). A further CP analysis was conducted using these criteria weights was conducted (MCDA-2).

\section{Results and Discussion}

The following sections outline the results obtained when: criteria included in the MCDA are considered individually, multiple criteria are considered simultaneously with equal weights (MCDA-1), and multiple criteria are considered simultaneously with weights ascertained by distillery management (MCDA-2).

\subsection{Consideration of individual criteria}

\subsubsection{Scope 1 GHG emissions}

When the only relevant criterion is Scope 1 GHG emissions, the MCDA results indicate that all by-products should be used in an AD plant. A summary of results is presented in Table 6, Figures 3 and 4.

\subsubsection{Scope 3 GHG emissions}

The results obtained when only Scope 3 GHG emissions are the same as the results obtained when only Scope 1 GHG emissions are considered.

\subsubsection{Other GHG emissions (imported animal feed)}

When the goal is to minimise the GHG emissions associated with the production and transport of potentially imported animal feed no byproducts should be used in an AD plant. Feed production at the distillery using all of the available by-products should continue. No Scope 1 or Scope 3 emissions savings would be achieved. This result is trivial and corresponds to a "do nothing" scenario.

\subsubsection{Loss of protein}

When the loss of protein is the only criteria considered, the MCDA analysis indicates that no by-products should be used in an AD plant as this minimises the loss of protein. In this case, no Scope 1 or Scope 3 emissions savings would be achieved, and no biogas would be produced. Distillery operations continue unchanged. This is also a "do nothing" scenario.

\subsubsection{Electrical energy savings in feed recovery plant}

Maximum electrical energy savings in the feed recovery plant would occur if all of the by-products were used in an $\mathrm{AD}$ plant. Results are identical to those obtained when Scope 1 savings or Scope 3 savings are the only criteria included.

\subsection{Impact of considering only Scope 1 savings, Scope 3 savings, and} electrical energy savings

When the only criterion assessed is either Scope 1 emissions savings, Scope 3 emissions savings, or electrical energy savings, the use of $100 \%$ of each by-product in an $\mathrm{AD}$ plant and enables all of these criteria to achieve their ideal values (distance to ideal value $\left(d_{\text {ideal }}\right)=0$, Fig. $3 \mathrm{~b}$ ). Use of all by-products maximises the production of biogas $(154 \mathrm{GWh} / \mathrm{a}$, equivalent to $67 \%$ of current gas consumption) which yields maximum Scope 1 
Table 6.

Multi criteria decision analysis (MCDA) results. 'GHG': Greenhouse Gas. 'N': Nitrogen. 'P': Phosphorous. 'DDG': Dried Distillers' Grains. 'ktwwt': Kilo-tonne Wet Weight of Material.

\begin{tabular}{|c|c|c|c|c|c|}
\hline Scenario & Unit & $\begin{array}{c}\text { Maximise: } \\
\text { Scope } 1 \text { Saving, } \\
\text { Scope } 3 \text { Saving, } \\
\text { Electrical Energy Saving }\end{array}$ & $\begin{array}{l}\text { Minimise: } \\
\text { Other GHG Emissions, } \\
\text { Protein Loss }\end{array}$ & MCDA-1 & MCDA-2 \\
\hline Share of Distillery Energy Use from Biogas & $\%$ & 67 & 0 & 34 & 48 \\
\hline Scope 1 GHG Savings from Biogas & $\mathrm{ktCO} 2 \mathrm{eq}$ & 30.99 & 0 & 15.94 & 22.20 \\
\hline Scope 1 GHG Savings from Feed Recovery Plant & ktCO2eq & 2.42 & 0 & 2.42 & 2.42 \\
\hline Scope 3 Category 3 Emissions Saving (Natural Gas) & $\mathrm{ktCO} 2 \mathrm{eq}$ & 3.97 & 0 & 2.18 & 2.93 \\
\hline Digestate GHG Emissions (Scope 3) & ktCO2eq & 11.15 & 0 & 4.96 & 6.40 \\
\hline Synthetic N Fertiliser: Mass N Replaced & $\mathrm{tN}$ & 1,181 & 0 & 606 & 841 \\
\hline Synthetic N Fertiliser GHG Savings (Scope 3) & ktCO2eq & 18.04 & 0 & 9.26 & 13.31 \\
\hline Synthetic P Fertiliser: Mass P Replaced & $\mathrm{tP}$ & 456 & 0 & 239 & 239 \\
\hline Synthetic P Fertiliser GHG Savings (Scope 3) & ktCO2eq & 0.52 & 0 & 0.273 & 0.272 \\
\hline Wet Grain Production & ktwwt & 0 & 62.77 & 43.67 & 0 \\
\hline Syrup Production & ktwwt & 0 & 41.79 & 29.68 & 38.98 \\
\hline Feed Product Transport GHG Emission Saving & $\mathrm{ktCO}_{2} \mathrm{eq}$ & 2.77 & 0 & 1.15 & 1.91 \\
\hline Distillers Grain Import & ktwwt & 30.06 & 0 & 15.47 & 19.59 \\
\hline Soymeal Import & ktwwt & 11.54 & 0 & 5.93 & 9.15 \\
\hline Distiller Grain GHG Emissions & $\mathrm{kgCO}_{2} \mathrm{eq}$ & 32.65 & 0 & 16.80 & 21.27 \\
\hline Soymeal GHG Emissions & $\mathrm{kgCO}_{2} \mathrm{eq}$ & 8.77 & 0 & 4.51 & 6.95 \\
\hline Landbank Area & ha & 18,257 & 0 & 9,564 & 9,541 \\
\hline
\end{tabular}

emissions savings $\left(27,748 \mathrm{tCO}_{2}\right.$ eq, equivalent to $60 \%$ of current Scope 1 emissions). Processing all by-products in an $\mathrm{AD}$ plant maximises digestate production and Scope 3 emissions savings (11,389 $\left.\mathrm{tCO}_{2} \mathrm{eq}\right)$. Electrical energy savings are maximised $(8,541 \mathrm{MWh} / \mathrm{a})$ as the FRP does not operate when all by-products are used in the $\mathrm{AD}$ plant.

However, using all by-products in an AD plant maximises the loss of protein $(13,544 \mathrm{t})$ and nutritional energy $\left(42,802 \times 10^{3} \mathrm{UFL}\right)$, and would maximise other emissions associated with potentially imported animal feed (38,642 $\left.\mathrm{tCO}_{2} \mathrm{eq}\right)$, all of which attain their nadir value $\left(d_{\text {ideal }}=1\right.$, Fig. $\left.3 \mathrm{~b}\right)$. Maximum loss of protein and nutritional energy production is undesirable as the distillery is seen as an essential source of high protein animal feed in the local agricultural sector. The mass of distillers' grains (30.06 ktwwt) and soybean meal (11.54 ktwwt) to be imported is equivalent to $5 \%$ and $2 \%$ of their respective imports into Ireland in 2018. Emissions associated with potentially imported animal feed may be substantial $\left(41.42 \mathrm{ktCO}_{2} \mathrm{eq}\right)$. Maximum digestate production $(597,545$ twwt/a) may thwart the implementation of an AD plant at the distillery owing to digestate management issues if digestate is not processed further. If the whole digestate was to be applied to land used for barley cultivation, a total of $18,257 \mathrm{ha}$ of land would be required. Digestate transportation up to $50 \mathrm{~km}$ from the $\mathrm{AD}$ plant would be required, which could be unviable from an economic and social acceptance standpoint. The transportation of this mass of digestate would require a substantial number of truck movements (O'Shea et al., 2020). Recent objections to the construction of large AD plants in Ireland on the basis of increased vehicle movements may render such a plant unviable. The use of digestate processing techniques is currently under investigation in order to minimise truck movements and storage volumes required.

At a global level, the total change in GHG emissions achieved is a saving of $495 \mathrm{tCO}_{2} \mathrm{eq} / \mathrm{a}$, when Scope 1 emission savings, Scope 3 emission savings, and other emissions from potentially imported animal feed are combined. The summation of Scope 1 emission savings, Scope 3 emission savings, and other emissions may not be additive, and therefore, this "total" value should be treated with caution. However, it is encouraging to see that when the only criteria included in the analysis were Scope 1 emission savings, Scope 3 emission savings, or electrical energy savings, there is the potential for an overall total GHG emission saving at a global level.

Focusing solely on achieving maximum possible savings in Scope 1 emissions and Scope 3 emissions is not recommended as this also maximises the undesirable impacts of integrating an $\mathrm{AD}$ plant with the distillery. The loss of protein production especially could be seen as a significant hurdle for the implementation of an AD plant using distillery by-products.

\subsection{Impact of considering only other GHG emissions or the loss of protein}

When the only relevant criterion considered is; other GHG emissions (potentially imported animal feed), or loss of protein, the MCDA suggests that no by-products should be used in an AD plant. This result is a "do nothing" scenario for the distillery, none of the drawbacks of AD plant integration at the distillery occur as no AD plant built. The elimination of the drawbacks associated with an $\mathrm{AD}$ plant also eliminates any of the benefits arising from the use of by-products in an $\mathrm{AD}$ plant. The need to reduce Scope 1 GHG emissions and Scope 3 emissions at the distillery makes this course of action undesirable unless other methods of reducing Scope 1 emissions and Scope 3 emissions can be identified.

\subsection{Multiple criteria selected by distillery management}

Results from MCDA-1 (equal criteria weights) indicate that $50 \%$ of thick stillage, $55 \%$ of thin stillage, and $50 \%$ of draff should be used in an AD plant, with the remaining by-products used to produce animal feed. Results are summarised in Figure 5. The application of digestate to the required landbank is summarised in Figure 6.

Results from MCDA-2 suggest that $100 \%$ of thick stillage, $0 \%$ of thin stillage, and $100 \%$ of draff should be used in an AD plant. The remaining thin stillage should be used to produce animal feed (syrup) in the feeds recovery plant. Results of MCDA-2 are summarised in Figure 7. The application of the whole digestate to the required landbank is summarised in Figure 8.

\subsection{Impact of considering multiple criteria selected by distillery management}

\subsubsection{Equal criteria weights (MCDA-1)}

In MCDA- 1 the $\mathrm{CP}$ analysis indicates that $50 \%$ of thick stillage, $55 \%$ of thin stillage, and $50 \%$ of draff should be used in the AD plant yielding 79 


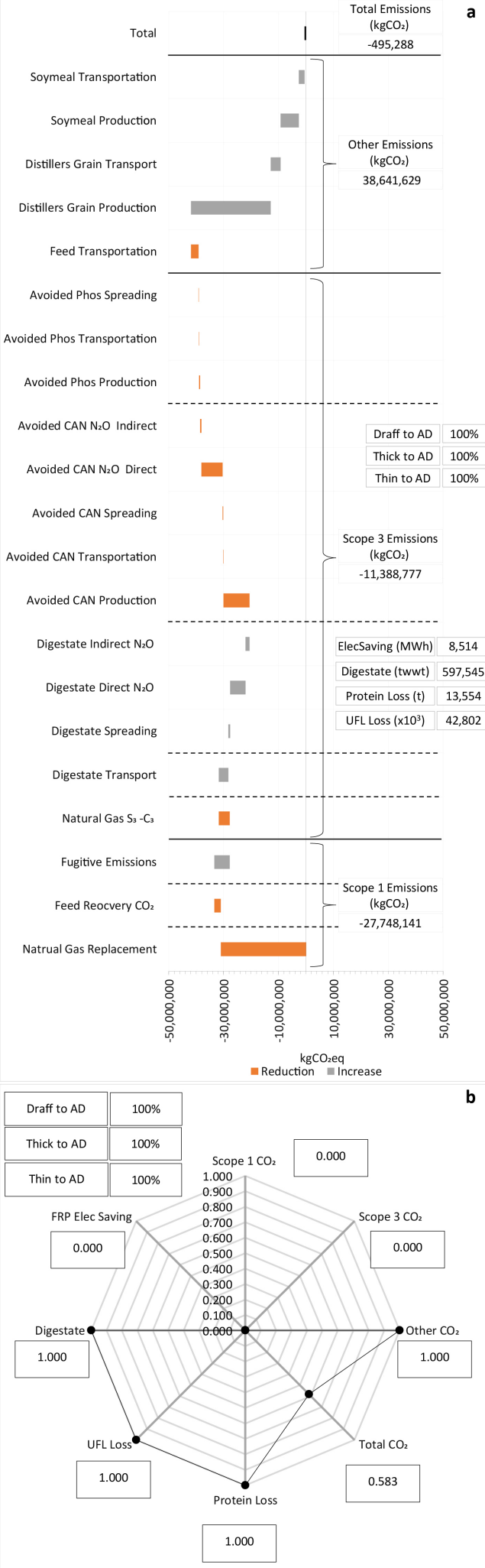

Fig. 3. Result when only considering Scope 1, Scope 3, or electricity savings. (a) Summary of results. (b) Deviation from Utopian value. 'CAN': Calcium Ammonia Nitrate. 'Phos': Phosphorous Fertiliser. 'Elec Saving': Electrical Energy Saving. 'UFL': Unité Forragére Lait. 'twwt': Tonne Wet Weight of Material. 'AD': Anaerobic Digestion. 'FRP': Feeds Recovery Plant. 'Thick': Thick Stillage. 'Thin': Thin Stillage.

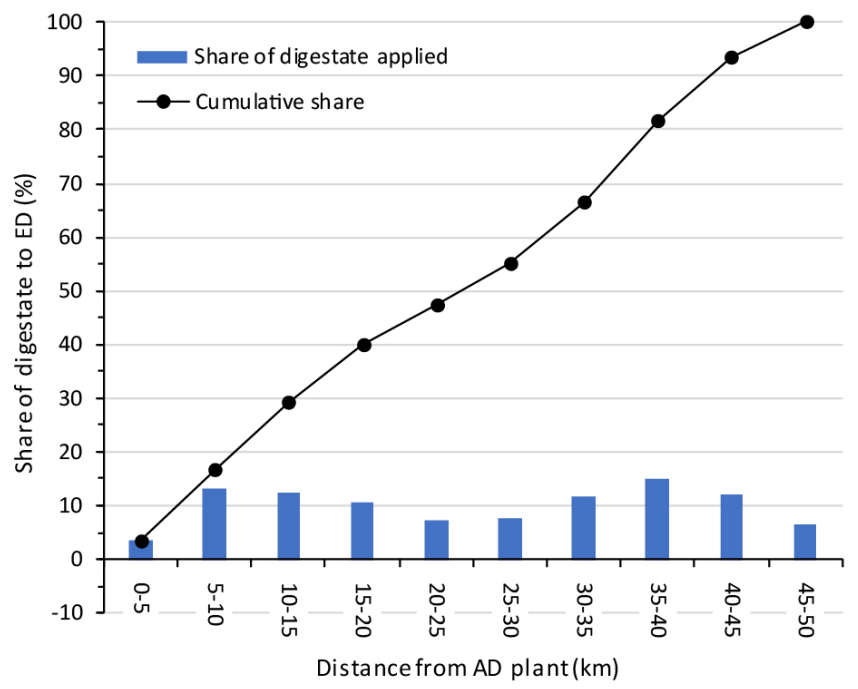

Fig. 4. Digestate management: Scope 1, Scope 3, or electricity savings only criteria considered. Share of digestate applied to landbank at a given distance. 'AD': Anaerobic Digestion. 'ED': Electoral Division.

$\mathrm{GWh} / \mathrm{a}$ of biogas, equivalent to $34 \%$ of current gas consumption. This is $51 \%$ of the biogas production achieved when all of the by-products are used in an $\mathrm{AD}$ plant. Scope $1 \mathrm{GHG}$ savings of $15,442 \mathrm{tCO}_{2}$ eq $\left(d_{\text {ideal }}=0.443\right)$ are equivalent to $33 \%$ of current Scope 1 GHG emissions from the distillery, this is lower than Scope 1 emission savings when only benefits of $\mathrm{AD}$ were to be maximised. Scope 3 emissions savings of 6,748 $\mathrm{tCO}_{2}$ eq $\left(d_{\text {ideal }}=0.407\right)$ could arise from the replacement of synthetic fertilisers used for barley cultivation by digestate. These Scope 3 emission savings are equivalent to $15 \%$ of the current Scope 1 emissions from the distillery. Scope 3 GHG savings are lower when multiple criteria are considered compared to when only Scope 3 savings is the criterion selected. Electrical energy savings of $6,086 \mathrm{MWh}\left(d_{\text {ideal }}=0.285\right)$ result from lower electricity consumption in the FRP. Electrical energy saving is lower when considering multiple criteria than when electrical energy saving is the only criteria considered.

Protein loss of $6,974 \mathrm{t}\left(d_{\text {ideal }}=0.515\right)$ and the loss of nutritional energy of $22,026 \times 10^{3}$ UFL $\left(d_{\text {ideal }}=0.515\right)$ would require the importation of 15.47 ktwwt of distillers' grains and 5.93 ktwwt of soybean meal resulting in other emissions of $20,166 \mathrm{tCO}_{2} \mathrm{eq}\left(d_{\text {ideal }}=0.522\right)$. These values are lower than those obtained when the goal was to maximise only the benefits of AD. The whole digestate produced amounted to $314.458 \mathrm{ktwwt}\left(d_{\text {ideal }}=0.526\right)$, which is $52.6 \%$ of the mass of digestate that would be produced if all byproducts were used in an AD plant. A landbank of 9,564 ha could be required for the whole digestate application. This is $52 \%$ of the land area required if all by-products were to be used in an $\mathrm{AD}$ plant. The whole digestate could require transportation to land up to $30 \mathrm{~km}$ from the $\mathrm{AD}$ plant, with the majority of digestate (70\%) applied to land between $5-20 \mathrm{~km}$ from the $\mathrm{AD}$ plant. Further processing of digestate via; separation, evaporation, pyrolysis, or gasification could digestate management issues. The specific impact of these digestate processing methods will be assessed in future work.

The use of by-products in MCDA-1 is approximately half of that used when the goal was to maximise the benefits of $\mathrm{AD}$. The reduction in byproduct use in an $\mathrm{AD}$ plant is a direct result of a compromise between maximising the benefits of by-product use in an $\mathrm{AD}$ plant and minimising the associated drawbacks. Figure $5 \mathrm{~b}$ indicates that the values achieved by the criteria considered in MCDA-1 fall between a normalised distance of 0.285 to 0.522 from their respective ideal values $\left(d_{\text {ideal }}\right)$. Figure $5 \mathrm{~b}$ also shows that criteria not included in the analysis for MCDA-1 (Total GHG emission savings, UFL loss, and digestate production) achieve values that fall between a normalised distance of 0.356 to 0.526 from their respective 


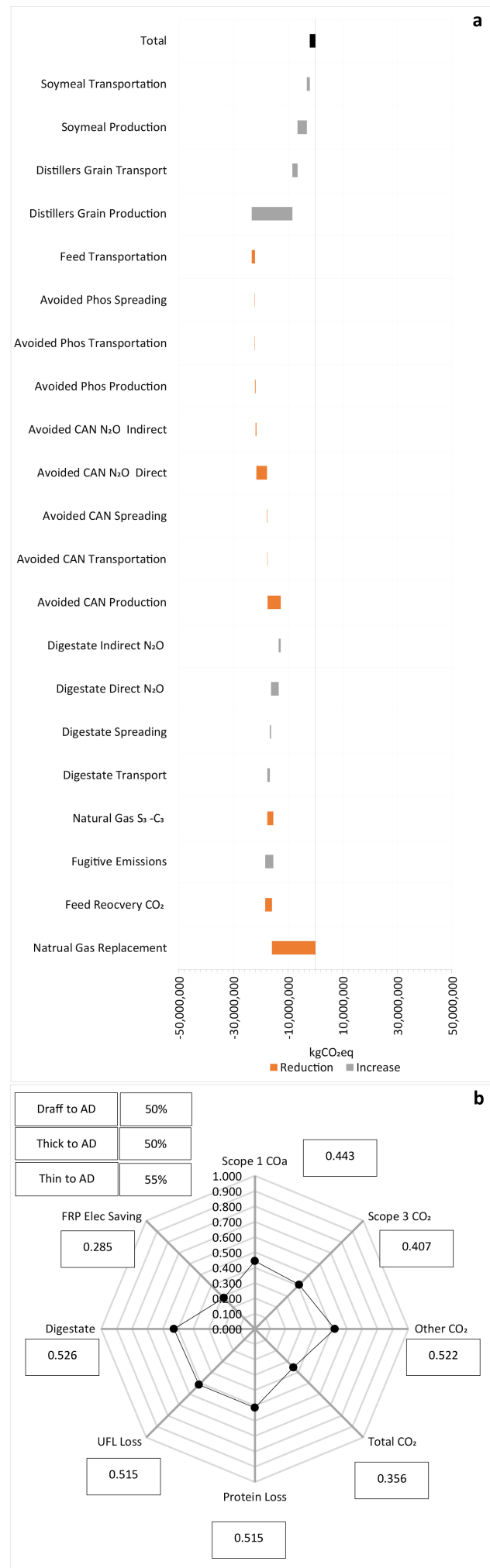

Fig. 5. MCDA-1: Scope 1, Scope 3, and electricity savings, protein loss, and other GHG emissions. Equal criteria weights. (a) Summary of results. (b) Deviation from Utopian value. 'CAN': Calcium Ammonia Nitrate. 'Phos': Phosphorous Fertiliser. 'Elec Saving': Electrical Energy Saving. 'UFL': Unité Forragére Lait. 'twwt': Tonne Wet Weight of Material. 'AD': Anaerobic Digestion. 'FRP': Feeds Recovery Plant. 'Thick': Thick Stillage. 'Thin': Thin Stillage. 'MCDA': Multi Criteria Decision Analysis. 'GHG': Greenhouse Gas.

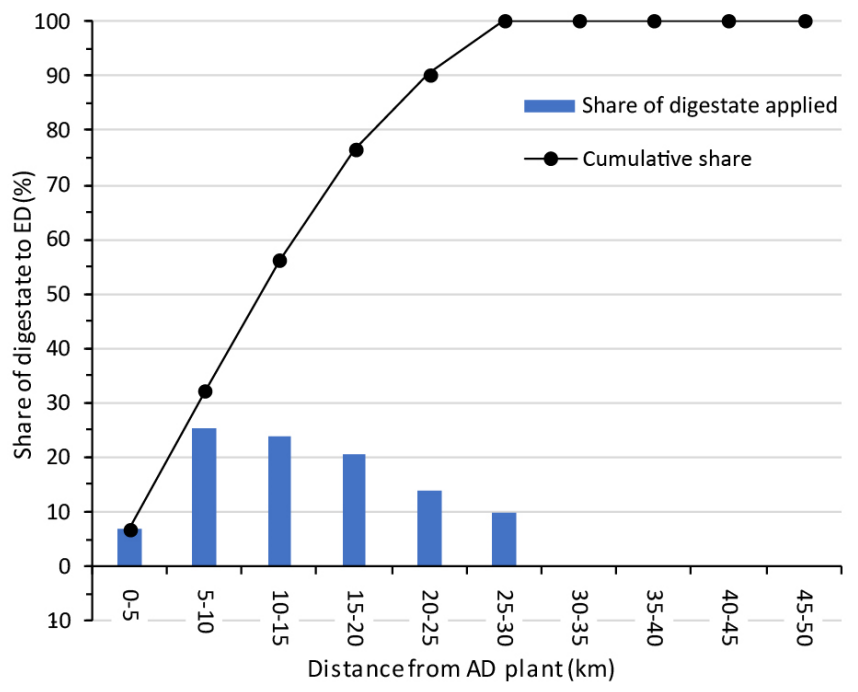

Fig. 6. Digestate management: results from MCDA-1. Share of digestate applied to landbank at a given distance. 'AD': Anaerobic Digestion. 'ED': Electoral Division. 'MCDA': Multi Criteria Decision Analysis.

ideals values. This indicates that in MCDA-1, neither the criteria considered in the analysis or the criteria not considered approach their nadir values.

The recommended use of ca. $50 \%$ of by-products in MCDA-1 appears to be trivial, this however, is not the case owing to the different properties of each by-product and the complex calculation procedures used herein Recommending the use of ca. $50 \%$ of by-products to balance the benefits and drawbacks of AD in the absence of any MCDA would simply be a lucky guess.

Results of MCDA-1 assume all criteria are equally important, which is a common approach to take as it removes the subjective nature of applying weights of importance to criteria. This can be beneficial as the relative degrees of importance of each criterion may change over time.

\subsubsection{Criteria weights specified by distillery management (MCDA-2)}

Based on the criteria weights obtained from distillery management (Table 5) greater emphasis is placed on Scope 1 and Scope 3 GHG emission savings, followed by protein loss, other GHG emissions from potentially imported animal feed, and finally, electrical energy savings. The assumption of equal criteria weights in MCDA-1 does not reflect the actual criteria weights obtained from distillery management for use in MCDA-2. MCDA- 2 suggests the use of $100 \%$ of thick stillage, $0 \%$ of thin stillage, and $100 \%$ of draff in an AD plant. This would yield $110 \mathrm{GWh}$ of biogas, equivalent to $48 \%$ of the natural gas consumption of the distillery. Biogas production is ca. $71 \%$ of the total biogas production if the goal was to maximise the benefits of AD. Biogas production in MCDA-2 $(110 \mathrm{GWh} / \mathrm{a})$ is 39\% higher than in MCDA-1 (79 GWh/a) as a result of higher weighting being placed on Scope 1 emission savings and Scope 3 emission savings.

Scope 1 GHG savings of $20,564 \mathrm{tCO}_{2} \mathrm{eq}\left(d_{\text {ideal }}=0.259\right)$ are $45 \%$ of current Scope 1 GHG emissions from the distillery. Scope 1 emission savings in MCDA-2 are 26\% lower than when only Scope 1 savings is the only criterion selected; however, they are $33 \%$ greater than Scope 1 emission savings in MCDA-1. This is a direct result of the increased weight applied to Scope 1 emission savings in MCDA-2 compared to MCDA-1. Scope 3 emissions savings of $10,105 \mathrm{tCO}_{2} \mathrm{eq}\left(d_{\text {ideal }}=0.113\right)$ are equivalent to $22 \%$ of current Scope $1 \mathrm{GHG}$ emissions. Scope 3 emission savings are $11 \%$ lower in MCDA-2 when compared to results obtained when Scope 3 emission savings is the only criterion considered. The Scope 3 emission savings obtained in MCDA-2 are 50\% higher than Scope 3 emission savings obtained in MCDA-1 as a result of the higher emphasis on Scope 3 emission savings in MCDA-2. Electrical energy savings of 5,442 $\mathrm{MWh}$ $\left(d_{\text {ideal }}=0.361\right)$ are obtained in MCDA-2; these savings are $36 \%$ lower 


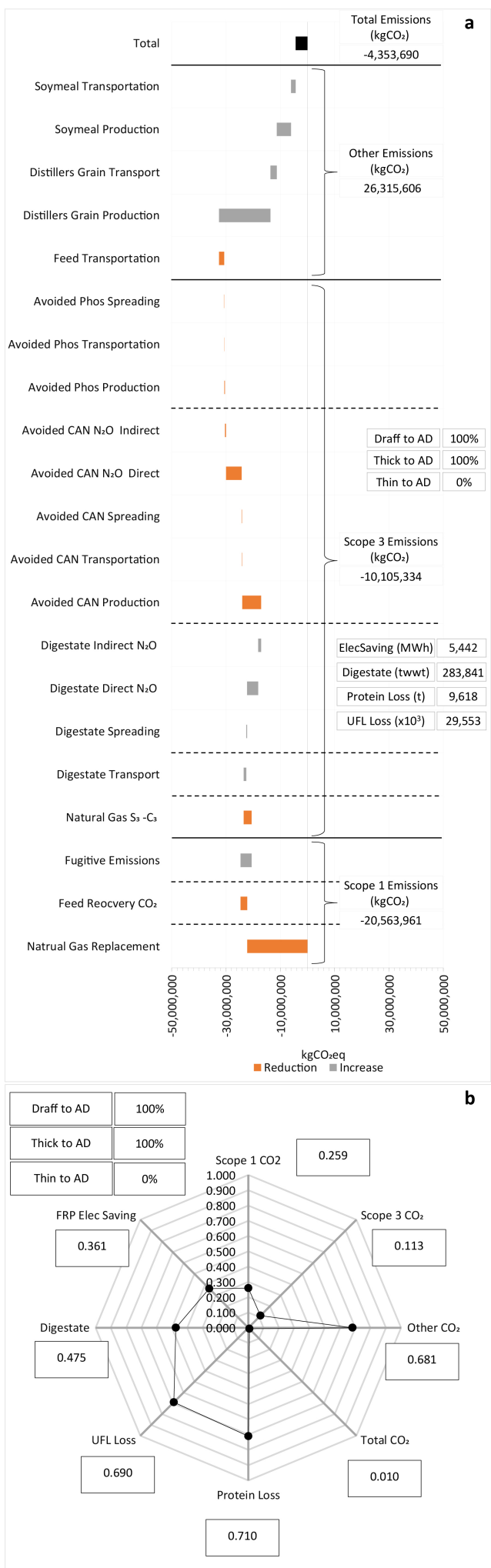

Fig. 7. MCDA-2: Scope 1, Scope 3, and electricity savings, protein loss, and other GHG emissions. Criteria weights from AHP. A) Summary of results. B) Deviation from Utopian value. 'CAN': Calcium Ammonia Nitrate. 'Phos': Phosphorous Fertiliser. 'Elec Saving': Electrical Energy Saving. 'UFL': Unité Forragére Lait. 'twwt': Tonne Wet Weight of Material. 'AD': Anaerobic Digestion. 'FRP': Feeds Recovery Plant. 'Thick': Thick Stillage. 'Thin': Thin Stillage. 'MCDA': Multi Criteria Decision Analysis. 'GHG': Greenhouse Gas.

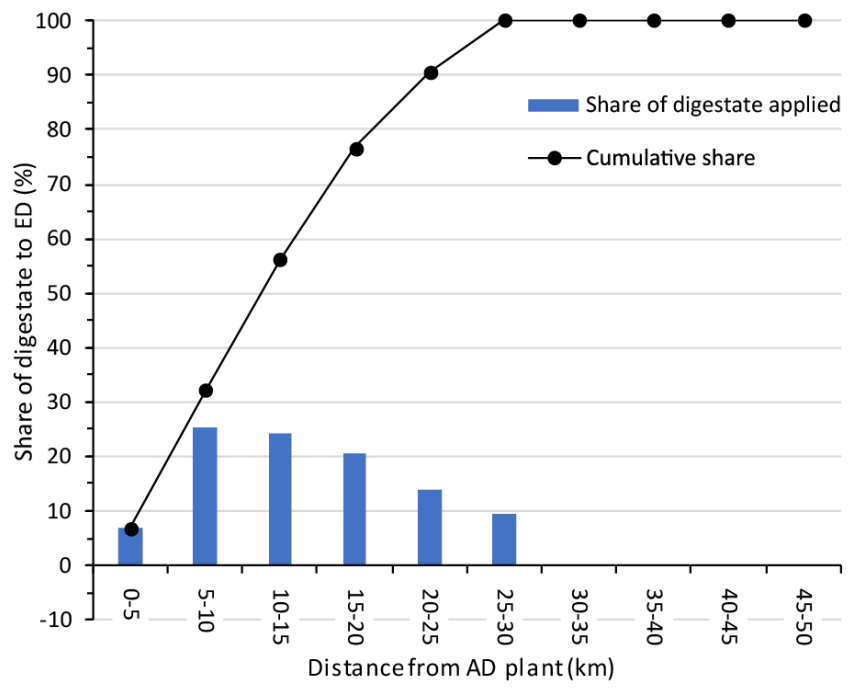

Fig. 8. Digestate management: results from MCDA-2. Share of digestate applied to landbank at a given distance. 'AD': Anaerobic Digestion. 'ED': Electoral Division. 'MCDA': Multi Criteria Decision Analysis.

compared to electrical energy savings when electrical energy saving is the only criterion considered. The electrical energy saving obtained in MCDA-2 is $10 \%$ lower than that obtained in MCDA-1 as a result of the lower weight applied to the electrical energy saving criterion in MCDA-2 (0.0296) compared to MCDA-1 (0.2).

Protein loss of $9,618 \mathrm{t}\left(d_{\text {ideal }}=0.710\right)$ and the loss of nutritional energy of $\left(29,553,026 \times 10^{3}\right.$ UFL $) d_{\text {ideal }}=0.69$ would require the import of 19.59 ktwwt of distillers' grains and 9.15 ktwwt of soybean meal resulting in other emissions of $26,316 \mathrm{tCO}_{2} \mathrm{eq}\left(d_{\text {ideal }}=0.681\right)$. These values are lower than those obtained when the goal was to maximise only the benefits of AD. Protein loss in MCDA-2 is 38\% higher than protein loss in MCDA-1, other emissions associated with potentially imported animal feed in MCDA-2 are $30 \%$ higher compared to other emissions in MCDA-1. These are a result of the increased mass of distillers grains and soybean meal which may need to be imported in MCDA-2 based on the lower weight associated with the protein loss criteria in MCDA-2, and the higher weight associated with Scope 1 and Scope 3 emission savings in MCDA-2 compared to MCDA-1 respectively.

Whole digestate produced in MCDA-2 amounted to 283,841 twwt $\left(d_{\text {ideal }}=0.475\right)$, which is $47.5 \%$ of the mass of digestate that would be produced if all by-products were used in an AD plant. The mass of whole digestate produced in MCDA-2 is $10 \%$ lower than the mass of whole digestate produced in MCDA-1 owing to the reduced use of thin stillage by the AD plant in MCDA-2. The use of thick stillage and draff is favoured in MCDA-2 in order to maximise Scope 1 and Scope 3 emission savings. A landbank of 9,541 ha could be required in MCDA-2, this is $52 \%$ of the land area required if all by-products were to be used in an $\mathrm{AD}$ plant and $99.8 \%$ of the land area required in MCDA-1. Despite the lower mass of digestate produced in MCDA-2 compared to MCDA-1 a similar land area is required for the application of whole digestate. The similar landbank area is a result of the total mass of phosphorous contained in the digestate $(239 \mathrm{t})$ in MCDA-1 and MCDA-2 being the same. Phosphorous is the rate limiting nutrient for land application of fertilisers, and therefore a similar land area would be required for the application of digestate. Transportation of digestate up to $30 \mathrm{~km}$ from the $\mathrm{AD}$ plant would be required, with the majority of digestate (70\%) applied to land within 5-20 km of the AD plant In reality, digestate processing will be required to mitigate the number of truck movements and storage volumes required for digestate management These processing techniques such as: separation, evaporation, combustion, pyrolysis, and gasification will be assessed in future work.

The compromise solution achieved in MCDA- 2 is substantially different to the compromise solution achieved in MCDA-1. The increased use of thick stillage and draff in MCDA-2 is a result of the higher weights applied 
to Scope 1 emission savings and Scope 3 emission savings in MCDA-2 compared to MCDA-1. Increased use of thick stillage and draff directly increases Scope 1 emission savings owing to increased biogas production and increases Scope 3 emission savings owing to the higher nitrogen and phosphorous content of these by-products compared to thin stillage, thereby replacing more synthetic fertilisers. Electricity savings achieved in MCDA-2 are lower than those obtained in MCDA-1 as the weight associated with this criterion in MCDA-2 is lower than in MCDA-1. Drawbacks associated with the use of by-products in an AD plant, such as the loss of protein production and the GHG emissions associated with potentially imported animal feed are greater in MCDA-2 compared to MCDA-1. This is a direct result of the lower weights applied to these criteria in MCDA-2.

Comparison of Figure $5 \mathrm{~b}$ and Figure $7 \mathrm{~b}$ shows that criteria with a higher weight in MCDA-2 compared to MCDA-1 achieve values that are closer to their ideal values. Criteria with lower weights in MCDA-2 compared to MCDA-1 attain values which are further from their ideal value. This is to be expected as criteria with higher weights in MCDA-2 are seen as being more important. The values achieved by the criteria considered in MCDA-2 fall between a normalised distance of 0.113 to 0.710 from their respective ideal values therefore, none of the criteria considered in MCDA-2 approach their nadir values. The alteration of criteria weights in MCDA-2 results in a compromise solution that favours the criteria assigned higher weights at the expense of criteria with lower weights

Figure $7 \mathrm{~b}$ also shows that the criteria which are not included in the analysis for MCDA-2 (Total emission savings, UFL loss, and digestate production) achieve values which fall between a normalised distance of 0.010 to 0.690 from their respective ideal values. None of the criteria which are not considered in MCDA-2 approach their nadir value. It is worth noting that the "Total emission savings" criteria, although not considered in MCDA-2, approaches its ideal value in MCDA-2, despite the increased emissions arising from potentially imported animal feed. This is because the increased Scope 1 and Scope 3 emission savings outweigh the increase in other emissions in MCDA-2.

The compromise solution achieved in MCDA-2 is based on criteria weights obtained from a single workshop with distillery management using the AHP method. These criteria weights and the criteria themselves may be altered or updated by distillery management in the future to arrive at a more refined reflection of their preferences. The results given in this work do not represent a conclusive and definite measure of the criteria selected by distillery management or the relative weighting of these criteria. The results presented are a snapshot in time of an iterative process which can incorporate changing opinions and priorities.

\subsection{The need for compromise}

$\mathrm{AD}$ of distillery by-products can result in major reductions to Scope $1 \mathrm{GHG}$ emissions by replacing natural gas with biogas. Electrical energy savings in the FRP by reducing by-product processing in the FRP can also be realised. The use of digestate as a fertiliser on land used for the cultivation of barley consumed by the distillery could reduce Scope 3 GHG emissions. However, the use of distillery by-products in an AD plant will reduce animal feed production and result in a loss of protein supplied to the livestock sector by the distillery. Imported replacement animal feed could result in significant GHG emissions associated with the production and transportation of these feeds.

There is a multitude of by-product combinations that can be used in an $\mathrm{AD}$ plant which results in confusion when trying to ascertain what the best combination is. Maximum benefits and maximum drawbacks occur when all of the by-products are used in an AD plant. Minimum benefits and minimum drawbacks occur when no by-products are used in an AD plant, neither of these extreme solutions are viable. To balance the positive and negative aspects of using distillery by-products in an $\mathrm{AD}$ plant a compromise must be made. This compromise mitigates the negative impacts of by-product use in an $\mathrm{AD}$ plant but also partially negates the positive impacts.

Selection of the share of each by-product to use in an AD plant in to balance these benefits and drawbacks is not trivial owing to the conflicting nature of the criteria considered and the vast number of potential by-product combinations to choose from $(9,261$ in this analysis). The use of the $\mathrm{CP}$ approach allows for systematic selection of an appropriate share of by-products to use in an $\mathrm{AD}$ plant so as to achieve a holistic and balanced result based on the relevant criteria selected.
The need to find a compromise between benefits and drawbacks in the implementation of $\mathrm{AD}$ within the wider $\mathrm{FB}$ sector is paramount to ensure that these renewable energy projects can be developed in an informed manner. The integration of AD with facilities in the FB sector is a potential way to reduce GHG emissions, especially in processes that require high temperature heat which are difficult to decarbonise. However, all AD projects will have beneficial and detrimental impacts on a range of often conflicting criteria. Many projects integrating AD into the FB sector will need to consider some of, and potentially more than, the criteria considered in this work. The use of MCDA techniques, such as CP, can aid in the identification of possible project designs that maximise beneficial results while minimising detrimental impacts.

\section{Conclusions}

From 9,261 scenarios assessed, the use of $50 \%$ of thick stillage, $55 \%$ of thin stillage, and $50 \%$ of draff in an $\mathrm{AD}$ plant is recommended based on criteria selected by distillery management, assuming equal criteria importance. This combination of by-product use could: reduce Scope 1 GHG emissions by $33 \%$; reduce Scope 3 GHG emissions by $6,748 \mathrm{tCO}_{2} \mathrm{eq}$; reduce electrical energy consumption in the feeds recovery plant by $71 \%$; maintain $48 \%$ of current protein production; and limit the GHG emissions from potentially imported animal feed to $52 \%$ of the maximum amount of GHG emissions from potentially imported animal feed when all byproducts are used in an $\mathrm{AD}$ plant.

Based on criteria selected by distillery management and accounting for relative levels of importance the use of $100 \%$ of thick stillage and $100 \%$ of draff in an AD plant is recommended. This combination of by-products could: reduce Scope 1 GHG emissions by $45 \%$; reduce Scope 3 GHG emissions by $10,105 \mathrm{tCO}_{2}$ eq; reduce electrical energy consumption in the feeds recovery plant by $63 \%$; maintain $29 \%$ of current protein production; and limit the GHG emissions from potentially imported animal feed to $68 \%$ of the maximum amount of GHG emissions from potentially imported animal feed when all by-products are used in an AD plant. Considering different criteria or applying different degrees of relative importance would result in a different compromise solution being recommended. The thesis presented in this work can be applied to other facilities in the FB sector to aid the design of $\mathrm{AD}$ projects whilst balancing potential benefits and drawbacks.

\section{Acknowledgements}

Dr Richard O'Shea is funded by IDL Pernod Ricard and SFI through the MaREI centre (12/RC/2302_P2). Dr Richen Lin recognises funding from the European Union's Horizon 2020 research and innovation programme under the Marie Skłodowska-Curie (grant number 797259) and the Environmental Protection Agency - Ireland (2018-RE-MS-13).

\section{References}

[1] Allen, E., Wall, D.M., Herrmann, C., Xia, A., Murphy, J.D., 2015 What is the gross energy yield of third generation gaseous biofuel sourced from seaweed?. Energy. 81, 352-360

[2] Berglund, M., Börjesson, P., 2006. Assessment of energy performance in the life-cycle of biogas production. Biomass Bioenergy. 30(3), 254-266.

[3] Blonk, H., Paassen, M., van, 2018. GFLI methodology and project guidelines. Gouda.

[4] Campos-Guzmán, V., García-Cáscales, M.S., Espinosa, N., Urbina, A., 2019. Life cycle analysis with multi-criteria decision making: a review of approaches for the sustainability evaluation of renewable energy technologies. Renew. Sust. Energy Rev. 104, 343-366.

[5] Canales, F.A., Jurasz, J., Beluco, A., Kies, A., 2020. Assessing temporal complementarity between three variable energy sources through correlation and compromise programming. Energy. 192, 116637.

[6] Capodaglio, A.G., Callegari, A., Lopez, M.V., 2016. European framework for the diffusion of biogas uses: emerging technologies, acceptance, incentive strategies, and institutional-regulatory support. Sustainability. 8(4), 298 
[7] Dahlin, J., Herbes, C., Nelles, M., 2015. Biogas digestate marketing: qualitative insights into the supply side. Resour. Conserv. Recycl. 104, $152-161$.

[8] de Sousa Xavier, A.M., Freitas, M. D. B. C., de Sousa Fragoso, R.M., 2015. Management of mediterranean forests-a compromise programming approach considering different stakeholders and different objectives. For. Policy Econ. 57, 38-46.

[9] Diakaki, C., Grigoroudis, E., Kolokotsa, D., 2008. Towards a multiobjective optimization approach for improving energy efficiency in buildings. Energy Build. 40(9), 1747-1754.

[10] Dieterich, B., Finnan, J., Hochstrasser, T., Müller, C., 2014. The greenhouse gas balance of a dairy farm as influenced by the uptake of biogas production. Bioenergy Res. 7(1), 95-109.

[11] Dong, H., Mangino, J., Mc Allister, T.A., Hatfield, J.L., Johnson, D.E., Lassey, K.R., de Lima, M.A., Romanovskaya, A., Bartram, D., Gibb, D., Martin, J.H., 2006. IPCC guidelines for national greenhouse gas inventories volume - IV agriculture, forestry and other land use, in: IPCC Guidelines for National Greenhouse Gas Inventories Volume - IV Agriculture, Forestry and Other Land Use. pp. 10.01-10.87.

[12] Dorini, G., Kapelan, Z., Azapagic, A., 2011. Managing uncertainty in multiple-criteria decision making related to sustainability assessment. Clean Technol. Environ. Policy. 13(1), 133-139.

[13] Drosg, B., Fuchs, W., Meixner, K., Waltenberger, R., Kirchmayr, R., Braun, R., Bochmann, G., 2013. Anaerobic digestion of stillage fractionsestimation of the potential for energy recovery in bioethanol plants. Water Sci. Technol. 67(3), 494-505.

[14] Drosg, B., Wirthensohn, T., Konrad, G., Hornbachner, D., Resch, C., Wäger, F., Loderer, C., Waltenberger, R., Kirchmayr, R., Braun, R., 2008. Comparing centralised and decentralised anaerobic digestion of stillage from a large-scale bioethanol plant to animal feed production. Water Sci. Technol. 58(7), 1483-1489.

[15] Duckstein, L., Opricovic, S., 1980. Multiobjective optimization in river basin development. Water Resour. Res. 16(1), 14-20.

[16] Duffy, P., Black, K., Hyde, B., Ryan, A., Ponzi, J., Alam, S., 2020. Ireland 's national inventory report 2020. Johnstown Castle, Wexford.

[17] Ellen MacArthur Foundation, 2013. Towards the circular economy: economic and business rationale for an accelerated transition.

[18] EPA, 2019. Country Specific Net Calorific Values and $\mathrm{CO}_{2}$ Emission Factors for use in the Annual Installation Emissions Report- 2019.

[19] Fagerström, A., Al Seadi, T., Rasi, S., Briseid, T., 2018. The role of anaerobic digestion and biogas in the circular economy. IEA Bioenergy Task 37.

[20] Foley, P.A., Crosson, P., Lovett, D.K., Boland, T.M., O’Mara, F.P., Kenny, D.A., 2011. Whole-farm systems modelling of greenhouse gas emissions from pastoral suckler beef cow production systems. Agric. Ecosyst. Environ. 142(3-4), 222-230.

[21] Hergoualc'h, K., Akiyama, H., Bernoux, M., Chirinda, N., Del Prado, A., Kasimir, Å., MacDonald, D., Ogle, S.M., Regina, K., Weerden, T.J.V.D., 2019. $\mathrm{N}_{2} \mathrm{O}$ Emissions from Managed Soils, and $\mathrm{CO}_{2}$ Emissions from Lime and Urea Application. IPCC. 4, 1-48.

[22] IEA, 2020. Outlook for biogas and biomethane. Prospects for organic growth. World Energy Outlook Special Report.

[23] IEA, 2018. World energy outlook 2018. Paris.

[24] Kang, X., Lin, R., O’Shea, R., Deng, C., Li, L., Sun, Y., Murphy, J.D., 2020. A perspective on decarbonizing whiskey using renewable gaseous biofuel in a circular bioeconomy process. J. Clean. Prod. 255, 120211.

[25] Korres, N.E., Singh, A., Nizami, A.S., Murphy, J.D., 2010. Is grass biomethane a sustainable transport biofuel?. Biofuels, Bioprod. Biorefin. 4(3), 310-325.

[26] Kumar, A., Sah, B., Singh, A.R., Deng, Y., He, X., Kumar, P., Bansal, R.C., 2017. A review of multi criteria decision making (MCDM) towards sustainable renewable energy development. Renew. Sust. Energy Rev. 69, 596-609.

[27] Leinonen, I., MacLeod, M., Bell, J., 2018. Effects of alternative uses of distillery by-products on the greenhouse gas emissions of Scottish malt whisky production: a system expansion approach. Sustainability. 10(5), 1473

[28] Lijó, L., González-García, S., Bacenetti, J., Fiala, M., Feijoo, G., Moreira, M.T., 2014. Assuring the sustainable production of biogas from anaerobic mono-digestion. J. Clean. Prod. 72, 23-34.
[29] Lindkvist, E., Karlsson, M., Ivner, J., 2019. System analysis of biogas production-part II application in food industry systems. Energies. 12(3), 412

[30] Logan, M., Visvanathan, C., 2019. Management strategies for anaerobic digestate of organic fraction of municipal solid waste: current status and future prospects. Waste Manage. Res. 37(1_suppl), 27-39.

[31] Lorenz, H., Fischer, P., Schumacher, B., Adler, P., 2013. Current EU 27 technical potential of organic waste streams for biogas and energy production. Waste Manage. 33(11), 2434-2448.

[32] Mardani, A., Zavadskas, E.K., Khalifah, Z., Zakuan, N., Jusoh, A. Nor, K.M., Khoshnoudi, M., 2017. A review of multi-criteria decision-making applications to solve energy management problems: two decades from 1995 to 2015. Renew. Sust. Energy Rev. 71, 216256.

[33] McAuliffe, G.A., Takahashi, T., Mogensen, L., Hermansen, J.E., Sage, C.L., Chapman, D.V., Lee, M.R.F., 2017. Environmental tradeoffs of pig production systems under varied operational efficiencies. J. Clean. Prod. 165, 1163-1173.

[34] Murphy, J.D., Thamsiriroj, T., 2013. 5-Fundamental science and engineering of the anaerobic digestion process for biogas production, in: The Biogas Handbook. Woodhead Publishing. Elsevier, pp. 104130 .

[35] Nemecek, T., Kagi, T., 2007. Life cycle inventories of agricultura production systems. Final report ecoinvent v2. 0 No, 15. 1-360.

[36] Nevzorova, T., Kutcherov, V., 2019. Barriers to the wider implementation of biogas as a source of energy: a state-of-the-ar review. Energy Strategy. Rev. 26, 100414.

[37] Nguyen, T.L.T., Hermansen, J.E., Mogensen, L.I.S.B.E.T.H., 2011. Environmental assessment of Danish pork. Report No. 103 Aarhus University.

[38] O’Shea, R., Lin, R., Wall, D.M., Browne, J.D., Murphy, J.D., 2020 Using biogas to reduce natural gas consumption and greenhouse gas emissions at a large distillery. Appl. Energy. 279, 115812.

[39] Panwar, M., Suryanarayanan, S., Hovsapian, R., 2017. A multi criteria decision analysis-based approach for dispatch of electric microgrids. Int. J. Electr. Power Energy Syst. 88, 99-107.

[40] Pipyn, P., Verstraete, W., Ombregt, J.P. 1979. A pilot scale anaerobic upflow reactor treating distillery wastewaters. Biotechnol. Lett. 1(12), 495-500.

[41] Plana, P.V., Noche, B., 2016. A review of the current digestate distribution models: storage and transport. Waste Manage. Environ. VIII 1, 345-357.

[42] Pöschl, M., Ward, S., Owende, P., 2010. Evaluation of energy efficiency of various biogas production and utilization pathways Appl. Energy. 87(11), 3305-3321.

[43] Sandgani, M.R., Sirouspour, S., 2018. Energy management in a network of grid-connected microgrids/nanogrids using compromise programming. IEEE Trans. Smart Grid. 9(3), 2180-2191.

[44] Reh1, T., Müiller, J., 2011. Life cycle assessment of biogas digestate processing technologies. Resour. Conserv. Recycl. 56(1), 92-104

[45] Rogelj, J., Shindell, D., Jiang, K., Fifita, S., Forster, P., Ginzburg, V. Handa, C., Kheshgi, H., Kobayashi, S., Kriegler, E., Mundaca, L. Séférian, R., Vilariño, M.V., 2018. Mitigation pathways compatible with $1.5^{\circ} \mathrm{C}$ in the context of sustainable development. In: Global Warming of $1.5^{\circ} \mathrm{C}$. An IPCC Special Report on the impacts of global warming of $1.5^{\circ} \mathrm{C}$ above pre-industrial levels and related global greenhouse gas emission pathw. IPCC Spec. Rep. Glob. Warm. 1.5 ${ }^{\circ} \mathrm{C} . \mathrm{pp} 82$.

[46] Romero, C., Amador, F., Barco, A., 1987. Multiple objectives in agricultural planning: a compromise programming application. Am. J. Agric. Econ. 69(1), 78-86

[47] Saaty, T.L., 1990. How to make a decision: the analytic hierarchy process. Eur. J. Oper. Res. 48(1), 9-26.

[48] Siksnelyte, I., Zavadskas, E.K., Streimikiene, D., Sharma, D., 2018 An overview of multi-criteria decision-making methods in dealing with sustainable energy development issues. Energies. 11(10), 2754.

[49] United Nations Framework Convention on Climate Change, 2019 Greenhouse gas inventory data - flexible queries annex I parties. 
[50] Wall, D.M., O’Kiely, P., Murphy, J.D., 2013. The potential for biomethane from grass and slurry to satisfy renewable energy targets. Bioresour. Technol. 149, 425-431.

[51] Wallace, M., 2020. Economic Impact assessment of the tillage sector in Ireland. Dublin

[52] Wang, S., Jena, U., Das, K.C., 2018. Biomethane production potential of slaughterhouse waste in the United States. Energy Convers. Manage. 173, 143-157.

[53] WBCSD and WRI, 2004. The greenhouse gas protocol a corporate accounting and reporting standard. Greenh. Gas Protoc. 1-116.

[54] WBCSD and WRI, 2013a. Corporate Value Chain (Scope 3) Accounting and Reporting Standard.

[55] WBCSD and WRI, 2013b. Technical Guidance for Calculating Scope 3 Emissions (version 1.0).

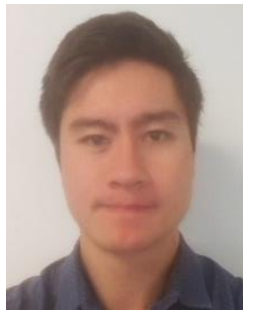

Dr. Richard O'Shea is a lecturer in the Science Foundation Ireland MaREI centre based in the Environmental Research Institute in University College Cork, Ireland. Dr. O'Shea received a Ph.D. in Energy Engineering from University College Cork in 2018. He has published 34 research articles in the academic press with an h-index of 15 and over 600 citations. His current research interests are anaerobic digestion, sustainability, multicriteria decision analysis, technoeconomic analysis, and decarbonization of the food and beverage industry. His Google Scholar profile can be found at the following link:

https://scholar.google.com/citations?user=dGm5ysAAAAAJ\&hl=en.

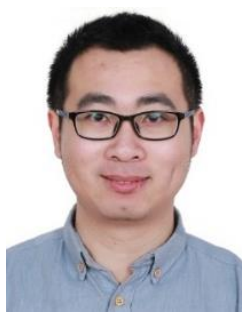

Dr. Richen Lin is a Lecturer in the Science Foundation Ireland MaREI centre based in the Environmental Research Institute in University College Cork, Ireland. $\mathrm{He}$ has a PhD degree in Energy and Environmental Engineering from Zhejiang University, China in 2016. He was a Marie Skłodowska-Curie Fellow (2018-2020) with a research focus on microbial electron transfer in anaerobic digestion. He has published over 60 peerreviewed journal papers with a h-index of 25 and over 1800 citations. His research interests include (1) bio/electrochemical $\mathrm{CO}_{2}$ valorisation; (2) cascading circular bio-based systems; and (3) negative carbon emission technologies, such as pyrochar. His research profile on Google Scholar can be found at the following link:

https://scholar.google.com/citations?user=otyeO6QAAAAJ\&hl=en.

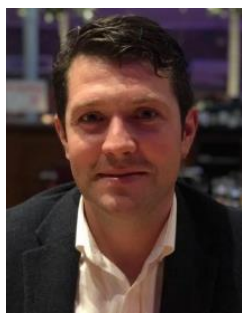

Dr. James Browne is Environmental and Energy Manager at Irish Distillers - Pernod Ricard. He was awarded a PhD in Engineering from UCC in 2014; his thesis was entitled "Biomethane production from food waste and organic residues." He previously worked with the Agri-Food and Biosciences Institute in Northern Ireland and with Gas Networks Ireland as an innovation manager. Though his career has been primarily with industry he has published 15 peer review journal papers in top academic press. His research profile on Google Scholar can be found at the following link:

https://scholar.google.com/citations?user=46kb7sEAAAAJ\&hl=en.
[56] Weber, B., Stadlbauer, E.A., 2017. Sustainable paths for managing solid and liquid waste from distilleries and breweries. J. Clean. Prod. $149,38-48$

[57] Yan, B., Yan, J., Li, Y., Qin, Y., Yang, L., 2021. Spatial distribution of biogas potential, utilization ratio and development potential of biogas from agricultural waste in China. J. Clean. Prod. 292, 126077

[58] Yu, P.L., 1985. Multiple-criteria decision making. Springer US, Boston, MA.

[59] Zelany, M., 1974. A concept of compromise solutions and the method of the displaced ideal. Comput. Oper. Res. 1(3-4), 479-496.

[60] Zeleny, M., 1976. The theory of the displaced ideal. In Multiple criteria decision making Kyoto. Springer, Berlin, Heidelberg. pp. 153-206.

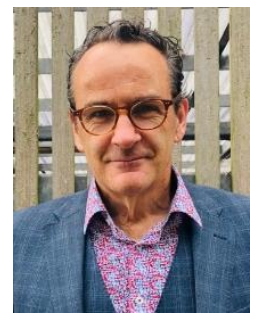

Prof. Jerry Murphy serves as the Director of the SFI funded MaREI centre for energy, climate, and marine, as Professor Chair of Civil Engineering at UCC, and as Leader of the Biogas Task at International Energy Agency (IEA) Bioenergy. He has authored and edited numerous IEA Bioenergy reports. He serves on the advisory board of a number of international organisations, including DBFZ (German Bioenergy Research Centre). He has authored over 170 peer-review journal papers and is listed in the top $2 \%$ of cited academics worldwide. His research profile is available at http://orcid.org/0000-0003-2120-1357.

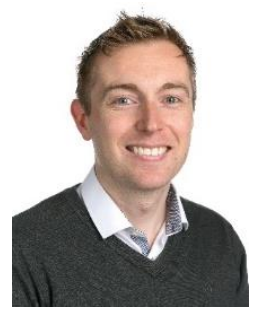

Dr. David Wall is a Lecturer in Transportation Engineering in the School of Engineering and Architecture at University College Cork (UCC). Dr. Wall was a previous Teagasc Walsh Fellow and obtained a PhD in Energy Engineering from UCC in 2015. Dr. Wall is a funded investigator in the Science Foundation Ireland (SFI) funded MaREI Centre for Energy, Climate and Marine, based in the Environmental Research Institute, UCC. He specialises on the topic of Advanced Fuels and the Circular Economy with a particular interest in electrofuels and cascading bioenergy systems. Dr. Wall has secured ca. $€ 1.4$ million in research funding. He has published over 30 peer reviewed journal papers (h-index of 23 with 1157 citations). Dr. Wall co-represents Ireland for the International Energy Agency (IEA) Bioenergy Task 37 on Biogas. His research profile on Google Scholar can be found at the following link: https://scholar.google.com/citations? user=b715XfkAAAAJ\&hl=en\&oi=sr a. 